\title{
Trajectories of nitrate input and output in three nested catchments along a land use gradient
}

\author{
Sophie Ehrhardt ${ }^{1}$, Rohini Kumar ${ }^{2}$, Jan H. Fleckenstein ${ }^{1,3}$, Sabine Attinger ${ }^{2}$, and Andreas Musolff ${ }^{1}$ \\ ${ }^{1}$ Department of Hydrogeology, Helmholtz-Centre for Environmental Research, 04318 Leipzig, Germany \\ ${ }^{2}$ Department Computational Hydrosystems, Helmholtz-Centre for Environmental Research, 04318 Leipzig, Germany \\ ${ }^{3}$ Bayreuth Center of Ecology and Environmental Research, University of Bayreuth, 95440 Bayreuth, Germany
}

Correspondence: Sophie Ehrhardt (sophie.ehrhardt@ufz.de)

Received: 6 September 2018 - Discussion started: 22 October 2018

Revised: 20 June 2019 - Accepted: 6 July 2019 - Published: 2 September 2019

\begin{abstract}
Increased anthropogenic inputs of nitrogen (N) to the biosphere during the last few decades have resulted in increased groundwater and surface water concentrations of $\mathrm{N}$ (primarily as nitrate), posing a global problem. Although measures have been implemented to reduce $\mathrm{N}$ inputs, they have not always led to decreasing riverine nitrate concentrations and loads. This limited response to the measures can either be caused by the accumulation of organic $\mathrm{N}$ in the soils (biogeochemical legacy) - or by long travel times (TTs) of inorganic $\mathrm{N}$ to the streams (hydrological legacy). Here, we compare atmospheric and agricultural $\mathrm{N}$ inputs with longterm observations (1970-2016) of riverine nitrate concentrations and loads in a central German mesoscale catchment with three nested subcatchments of increasing agricultural land use. Based on a data-driven approach, we assess jointly the $\mathrm{N}$ budget and the effective TTs of $\mathrm{N}$ through the soil and groundwater compartments. In combination with long-term trajectories of the $C-Q$ relationships, we evaluate the potential for and the characteristics of an $\mathrm{N}$ legacy.

We show that in the 40-year-long observation period, the catchment $\left(270 \mathrm{~km}^{2}\right)$ with $60 \%$ agricultural area received an $\mathrm{N}$ input of $53437 \mathrm{t}$, while it exported $6592 \mathrm{t}$, indicating an overall retention of $88 \%$. Removal of $\mathrm{N}$ by denitrification could not sufficiently explain this imbalance. Log-normal travel time distributions (TTDs) that link the $\mathrm{N}$ input history to the riverine export differed seasonally, with modes spanning 7-22 years and the mean TTs being systematically shorter during the high-flow season as compared to low-flow conditions. Systematic shifts in the $C-Q$ relationships were noticed over time that could be attributed to strong changes in $\mathrm{N}$ inputs resulting from agricultural intensification before
\end{abstract}

1989, the break-down of East German agriculture after 1989 and the seasonal differences in TTs. A chemostatic export regime of nitrate was only found after several years of stabilized $\mathrm{N}$ inputs. The changes in $C-Q$ relationships suggest a dominance of the hydrological $\mathrm{N}$ legacy over the biogeochemical $\mathrm{N}$ fixation in the soils, as we expected to observe a stronger and even increasing dampening of the riverine $\mathrm{N}$ concentrations after sustained high $\mathrm{N}$ inputs. Our analyses reveal an imbalance between $\mathrm{N}$ input and output, long timelags and a lack of significant denitrification in the catchment. All these suggest that catchment management needs to address both a longer-term reduction of $\mathrm{N}$ inputs and shorterterm mitigation of today's high $\mathrm{N}$ loads. The latter may be covered by interventions triggering denitrification, such as hedgerows around agricultural fields, riparian buffers zones or constructed wetlands. Further joint analyses of $\mathrm{N}$ budgets and TTs covering a higher variety of catchments will provide a deeper insight into $\mathrm{N}$ trajectories and their controlling parameters.

\section{Introduction}

In terrestrial, freshwater and marine ecosystems nitrogen $(\mathrm{N})$ species are essential and often limiting nutrients (Webster et al., 2003; Elser et al., 2007). Changes in strength of their different sources like atmospheric deposition, wastewater inputs and agricultural activities caused major changes in the $\mathrm{N}$ cycle (Webster et al., 2003). In particular, two major innovations from the industrial age accelerated anthropogenic inputs of reactive $\mathrm{N}$ species into the environment: artificial 
$\mathrm{N}$ fixation and the internal combustion engine (Elser, 2011). Therefore the amount of reactive $\mathrm{N}$ that enters into the element's biospheric cycle has been doubled in comparison to the preindustrial era (Smil, 1999; Vitousek et al., 1997). However, the different input sources of $\mathrm{N}$ show diverging rates of change over time and space. While the atmospheric emissions of $\mathrm{N}$ oxides and ammonia have strongly declined in Europe since the 1980s (EEA, 2014), the agricultural N input through fertilizers declined but is still at a high level (Federal Ministry for the Environment and Federal Ministry of Food, 2012). In the cultural landscape of western countries, most of the $\mathrm{N}$ emissions in surface and groundwater bodies stem from diffuse agricultural sources (Bouraoui and Grizzetti, 2011; Dupas et al., 2013).

The widespread consequences of these excessive $\mathrm{N}$ inputs are significantly elevated concentrations of dissolved inorganic nitrogen (DIN) in groundwater and connected surface waters (Altman and Parizek, 1995; Sebilo et al., 2013; Wassenaar, 1995), leading to increased riverine DIN fluxes (Dupas et al., 2016) and causing the ecological degradation of freshwater and marine systems. This degradation is caused by the ability of $\mathrm{N}$ species to increase primary production and to change food web structures (Howarth et al., 1996; Turner and Rabalais, 1991). In particular, the coastal marine environments, where nitrate $\left(\mathrm{NO}_{3}\right)$ is typically the limiting nutrient, are affected by these eutrophication problems (Decrem et al., 2007; Prasuhn and Sieber, 2005).

Several initiatives in the form of international, national and federal regulations have been implemented, aiming at an overall reduction of $\mathrm{N}$ inputs into the terrestrial system and its transfer to the aquatic system. In the European Union, guidelines are provided to its member states for national programs of measures and evaluation protocols through the Nitrate Directive (CEC, 1991) and the Water Framework Directive (CEC, 2000).

The evaluation of interventions showed that policy-makers still struggle to set appropriate goals for water quality improvement, particularly in heavily human-impacted watersheds. Studies in Europe and the United States showed that interventions like reduced $\mathrm{N}$ inputs mainly in agricultural land use do not immediately result in declining riverine $\mathrm{NO}_{3}-\mathrm{N}$ concentrations (Bouraoui and Grizzetti, 2011; Sprague et al., 2011; Howden et al., 2011) and fluxes (Worrall et al., 2009), although fast responding headwaters have been reported as well (Rozemeijer et al., 2014).

In Germany considerable progress has been achieved in the improvement of water quality, but the diffuse water pollution from agricultural sources continues to be of concern (Wendland et al., 2005). This limited response to mitigation measures can partly be explained by nutrient legacy effects, which stem from an accumulation of excessive fertilizer inputs over decades creating a strongly dampened response between the implementation of measures and water quality improvement (van Meter and Basu, 2015). Furthermore, the multi-year travel times (TTs) of nitrate through the soil and groundwater compartments cause large time lags (Howden et al., 2010; Melland et al., 2012) that can substantially delay the riverine response to applied management interventions. For a targeted and effective water quality management, we therefore need a profound understanding of the processes and controls of time lags of $\mathrm{N}$ from the source to groundwater and surface water bodies. Bringing together $\mathrm{N}$ balancing and accumulation with estimations of N TTs from application to riverine exports can contribute to this lack of knowledge.

Estimation of the water or solute TTs is essential for predicting the retention, mobility and fate of solutes, nutrients and contaminants at catchment scale (Jasechko et al., 2016). Time series of solute concentrations and loads that cover both input to the geosphere and the subsequent riverine export can be used not only to determine TTs (van Meter and Basu, 2017), but also to quantify mass losses in the export as well as the behavior of the catchment's retention capacity (Dupas et al., 2015). Knowledge on the TT of N would therefore allow understanding on the $\mathrm{N}$ transport behavior, defining the fate of injected $\mathrm{N}$ mass into the system and its contribution to riverine $\mathrm{N}$ response. The mass of $\mathrm{N}$ being transported through the catchment storage can be referred to as hydrological legacy. Data-driven or simplified mechanistic approaches have often been used to derive stationary and seasonally variable travel time distributions (TTDs) using input and output signals of conservative tracers or isotopes (Jasechko et al., 2016; Heidbüchel et al., 2012) or chloride concentrations (Kirchner et al., 2000; Bennettin et al., 2015). Recently, van Meter and Basu (2017) estimated the solute TTs for $\mathrm{N}$ transport at several stations across a catchment located in Southern Ontario, Canada, showing decadal timelags between input and riverine exports. Moreover, systematic seasonal variations in the $\mathrm{NO}_{3}-\mathrm{N}$ concentrations have been found, which were explained by seasonal shifts in the $\mathrm{N}$ delivery pathways and connected time lags (van Meter and Basu, 2017). Despite the determination of such seasonal concentration changes and age dynamics, there are relatively few studies focussing on their long-term trajectory under conditions of changing $\mathrm{N}$ inputs (Dupas et al., 2018; Howden et al., 2010; Minaudo et al., 2015; Abbott et al., 2018). Seasonally differing time shifts, resulting in changing intra-annual concentration variations are of importance to aquatic ecosystems' health and their functionality. Seasonal concentration changes can also be directly connected to changing concentration-discharge $(C-Q)$ relationships a tool for classifying observed solute responses to changing discharge conditions and for characterizing and understanding anthropogenic impacts on solute input, transport and fate (Jawitz and Mitchell, 2011; Musolff et al., 2015). Investigations of temporal dynamics in the $C-Q$ relationship are a valuable addition to approaches based on $\mathrm{N}$ balancing only (e.g., Abbott et al., 2018), when evaluating the effect of management interventions.

The $C-Q$ relationships can be on the one hand classified in terms of their pattern, characterized by the slope $b$ of the 
$\ln (C)-\ln (Q)$ regression (Godsey et al., 2009): with enrichment $(b>0)$, dilution $(b<0)$ or constant $(b \approx 0)$ patterns (Musolff et al., 2017). On the other hand, $C-Q$ relationships can be classified according to the ratio between the coefficients of variation of concentration $\left(\mathrm{CV}_{C}\right)$ and of discharge $\left(\mathrm{CV}_{Q}\right.$; Thompson et al., 2011). This export regime can be either chemodynamic $\left(\mathrm{CV}_{C} / \mathrm{CV}_{Q}>0.5\right)$ or chemostatic, where the variance of the solute load is more dominated by the variance in discharge than the variance in concentration (Musolff et al., 2017). Both patterns and regimes are dominantly shaped by the spatial distribution of solute sources (Seibert et al., 2009; Basu et al., 2010; Thompson et al., 2011; Musolff et al., 2017). High source heterogeneity and consequently high concentration variability is thought to be characteristic for nutrients under pristine conditions (Musolff et al., 2017; Basu et al., 2010). It was shown in Germany and the United States that catchments under intensive agricultural use evolve from chemodynamic to more chemostatic behavior regarding nitrate export (Thompson et al., 2011; Dupas et al., 2016). Several decades of human N inputs seem to dampen the discharge-dependent concentration variability, resulting in chemostatic behavior, where concentrations are largely independent of discharge variations (Dupas et al., 2016). Also Thompson et al. (2011) stated observational and model-based evidence of an increasing chemostatic response of nitrate with increasing agricultural intensity. This shift in the export regimes is caused by a long-term homogenization of the nitrate sources in space and/or at depth within soils and aquifers (Dupas et al., 2016; Musolff et al., 2017). However, effective denitrification in the subsurface can create concentration variability over depths and flow path age and thus has been shown to result in chemodynamic exports even with intensive agriculture (van der Velde et al., 2010; Musolff et al., 2017). Long-term $N$ inputs lead to a loading of all flow paths in the catchment with mobile fractions of $\mathrm{N}$ and by that the formation of a hydrological N legacy (van Meter and Basu, 2015) and chemostatic riverine $\mathrm{N}$ exports. On the other hand, excessive fertilizer input is linked to the above-mentioned buildup of legacy $\mathrm{N}$ stores in the catchment, changing the export regime from a supply- to a transport-limited chemostatic one (Basu et al., 2010). This legacy is manifested as a biogeochemical legacy in the form of increased, less mobile, organic N content within the soil (Worral et al., 2015; van Meter and Basu, 2015; van Meter et al., 2017a). This type of legacy buffers biogeochemical variations, so that management measures can only show their effect if the buildup source gets substantially depleted (Basu et al., 2010).

Depending on the catchment configuration, both forms of legacy - hydrological and biogeochemical - can exist with different shares of the total $\mathrm{N}$ stored in a catchment (van Meter et al., 2017a). However, biogeochemical legacy is hard to distinguish from hydrological legacy when looking at time lags between $\mathrm{N}$ input and output or at catchment-scale $\mathrm{N}$ budgets only (van Meter and Basu, 2015). One way to better disentangle the $\mathrm{N}$ legacy types is applying the framework of
$C-Q$ relationships as defined by Jawitz and Mitchell (2011) and Musolff et al. $(2015,2017)$. In the case of a hydrological legacy, strong changes in fertilizer inputs (such as increasing inputs in the initial phase of intensification and decreasing inputs as a consequence of measures) will temporarily increase spatial concentration heterogeneity (e.g., comparing young and old water fractions in the catchment storage), and therefore also shift the export regime to more chemodynamic conditions. On the other hand, a dominant biogeochemical legacy will lead to sustained concentration homogeneity in the $\mathrm{N}$ source zone in the soils and to an insensitivity of the riverine $\mathrm{N}$ export regime to fast changes in inputs.

Common approaches to quantify catchment-scale $\mathrm{N}$ budgets and to characterize legacy or to derive TTs are either based on data-driven (Worral et al., 2015; Dupas et al., 2016) or on forward-modeling (van Meter and Basu, 2015; van Meter et al., 2017a) approaches. So far, data-driven studies focused either solely on $\mathrm{N}$ budgeting and legacy estimation or on TTs. Here, we conducted a joint data-driven assessment of the catchment-scale $\mathrm{N}$ budget, the potential and characteristics of an $\mathrm{N}$ legacy, and the estimation of TTs of the riverine exported $\mathrm{N}$. We utilized the trajectory of agricultural catchments in terms of $C-Q$ relationships, their changes over longer timescales and their potential evolution to a chemostatic export regime. The novel combination of the long-term $\mathrm{N}$ budgeting, TT estimation and $C-Q$ trajectory will help understanding of the differentiation between biogeochemical and hydrological legacy, both reasons for missed targets in water quality management. This study will address the following research questions:

1. How high is the retention potential for $\mathrm{N}$ of the studied mesoscale catchment and what are the consequences in terms of a potential buildup of an $\mathrm{N}$ legacy?

2. What are the characteristics of the TTD for $\mathrm{N}$ that links change in the diffuse anthropogenic $\mathrm{N}$ inputs to the geosphere and their observable effect in riverine $\mathrm{NO}_{3}-\mathrm{N}$ concentrations?

3. What are the characteristics of a long-term trajectory of $C-Q$ relationships? Is there an evolution to a chemostatic export regime that can be linked to a biogeochemical or hydrological $\mathrm{N}$ legacy?

To answer these questions, we used time series of water quality data over four decades, available from a mesoscale German catchment, as well as estimated $\mathrm{N}$ input to the geosphere. We linked $\mathrm{N}$ input and output on annual and intraannual timescales through consideration of $\mathrm{N}$ budgeting and the use of TTDs. This input-output assessment uses time series of the Holtemme catchment $\left(270 \mathrm{~km}^{2}\right)$ with its three nested subcatchments along a land use gradient from pristine mountainous headwaters to a lower basin with intensive agriculture and associated increases in fertilizer applications. This catchment, with its pronounced increase in anthropogenic impacts from up- to downstream, is quite typical 
for many mesoscale catchments in Germany and elsewhere. Moreover, this catchment offers a unique possibility to analyze the system response to strong changes in fertilizer usage in East Germany before and after reunification. Thereby, we anticipate that our improved understanding gained through this study in these catchment settings is transferable to similar regions. In comparison to spatially and temporally integrated water quality signals stemming solely from the catchment outlet, the higher spatial resolution with three stations and the unique length of the monitoring period (1970-2016) allow for a more detailed investigation about the fate of $\mathrm{N}$, and consequently findings may provide guidance for effective water quality management.

\section{Data and methods}

\subsection{Study area}

The Holtemme catchment $\left(270 \mathrm{~km}^{2}\right)$ is a subcatchment of the Bode River basin, which is part of the TERENO (TERrestrial ENvironmental Observatories) Harz/Central German Lowland Observatory (Fig. 1). The catchment, as part of the TERENO project, exhibits strong gradients in topography, climate, geology, soils, water quality, land use and level of urbanization (Wollschläger et al., 2017). Due to the low water availability and the risk of summer droughts that might be further exacerbated by a decrease in summer precipitation and increased evaporation with rising temperatures, the region is ranked as highly vulnerable to climate change (Schröter et al., 2005; Samaniego et al., 2018). With these conditions, the catchment is representative of other German and central European regions showing similar vulnerability (Zacharias et al., 2011). The observatory is one of the meteorologically and hydrologically best-equipped catchments in Germany (Zacharias et al., 2011; Wollschläger et al., 2017) and provides long-term data for many environmental variables including water quantity (e.g., precipitation, discharge) and water quality at various locations.

The Holtemme catchment has its spring at $862 \mathrm{~m}$ a.s.l. in the Harz Mountains and extends to the northeast to the central German lowlands with an outlet at $85 \mathrm{~m}$ a.s.l. The longterm annual mean precipitation (1951-2015) shows a remarkable decrease from a colder and humid climate in the Harz Mountains $(1262 \mathrm{~mm}$ ) down to the warmer and dryer climate of the central German lowlands on the leeward side of the mountains $(614 \mathrm{~mm}$; Rauthe et al., 2013; Frick et al., 2014). Discharge time series, provided by the State Office of Flood Protection and Water Management (LHW) of Saxony-Anhalt show a mean annual discharge at the outlet in Nienhagen of $1.5 \mathrm{~m}^{3} \mathrm{~s}^{-1}$ (1976-2016), corresponding to $172 \mathrm{~mm} \mathrm{a}^{-1}$.

The geology of the catchment is dominated by late Paleozoic rocks in the mountainous upstream part that are largely covered by Mesozoic rocks as well as Tertiary and Quater- nary sediments in the lowlands (Frühauf and Schwab, 2008; Schuberth, 2008). Land use of the catchment changes from forests in the pristine, mountainous headwaters to intensive agricultural use in the downstream lowlands (EEA, 2012). According to Corine Land Cover (CLC) from different years $(1990,2000,2006,2012)$, the land use change over the investigated period is negligible. Overall $60 \%$ of the catchment is used for agriculture, with a crop rotation of wheat, barley, triticale, rye and rapeseed (Yang et al., 2018b), while $30 \%$ is covered by forest (EEA, 2012). Urban land use occupies $8 \%$ of the total catchment area (EEA, 2012) with two major towns (Wernigerode, Halberstadt) and several small villages. Two wastewater treatment plants (WWTPs) discharge into the river. The town of Wernigerode had its WWTP within its city boundaries until 1995, when a new WWTP was put into operation about $9.1 \mathrm{~km}$ downstream in a smaller village, called Silstedt, replacing the old WWTP. The WWTP in Halberstadt was not relocated but renovated in 2000. Nowadays, the total nitrogen load (TNb) in cleaned water is approximately $67.95 \mathrm{~kg} \mathrm{~d}^{-1}$ (WWTP Silstedt: $\mathrm{NO}_{3}-\mathrm{N}$ load $55 \mathrm{~kg} \mathrm{~d}^{-1}$ ) and $35.09 \mathrm{~kg} \mathrm{~d}^{-1}$ (WWTP Halberstadt: $\mathrm{NO}_{3}-\mathrm{N}$ load $6.7 \mathrm{~kg} \mathrm{~d}^{-1}$; mean daily loads 2014; Müller et al., 2018). Referring to the last 5 years of observations, $\mathrm{NO}_{3}-\mathrm{N}$ load from wastewater made up $17 \%$ of the total observed $\mathrm{NO}_{3}-$ $\mathrm{N}$ flux at the midstream station (see below) and $11 \%$ at the downstream station. Despite this point source $\mathrm{N}$ input, the major nitrate contribution is due to inputs from agricultural land use (Müller et al., 2018), which is predominant in the mid- and downstream part of the catchment (Fig. 1).

The Holtemme River has a length of $47 \mathrm{~km}$. Along the river, the LHW of Saxony-Anhalt maintains long-term monitoring stations, providing the daily mean discharge and the biweekly to monthly water quality measurements covering roughly the last four decades (1970-2016). Three of the water quality stations along the river were selected to represent the characteristic land use and topographic gradient in the catchment. From up- to downstream, the stations are named Werbat, Derenburg and Nienhagen (Fig. 1) and in the following are referred to as upstream, midstream and downstream. The pristine headwaters upstream represent the smallest (6\% of total catchment area) and the steepest area among the three selected subcatchments with a mean topographic slope about 3 times higher than the downstream parts (DGM25; Table 1). According to the latest Corine Land Cover dataset (CLC, 2012; EEA, 2012), the land use is characterized by forest only. The larger midstream subcatchment that represents one-third of the total area is still dominated by forests, but with growing anthropogenic impact due to increasing agricultural land use and the town of Wernigerode. More than half of the agricultural land in this subcatchment is artificially drained with open ditches (midstream: $38 \%$, downstream: $82 \%$ ) and tube drains (midstream: $62 \%$, downstream: 18\%; LHW, 2011; Table 1; Fig. S1.1 in the Supplement). The largest subcatchment $(61 \%)$ constitutes the downstream lowland areas which are predominantly covered 


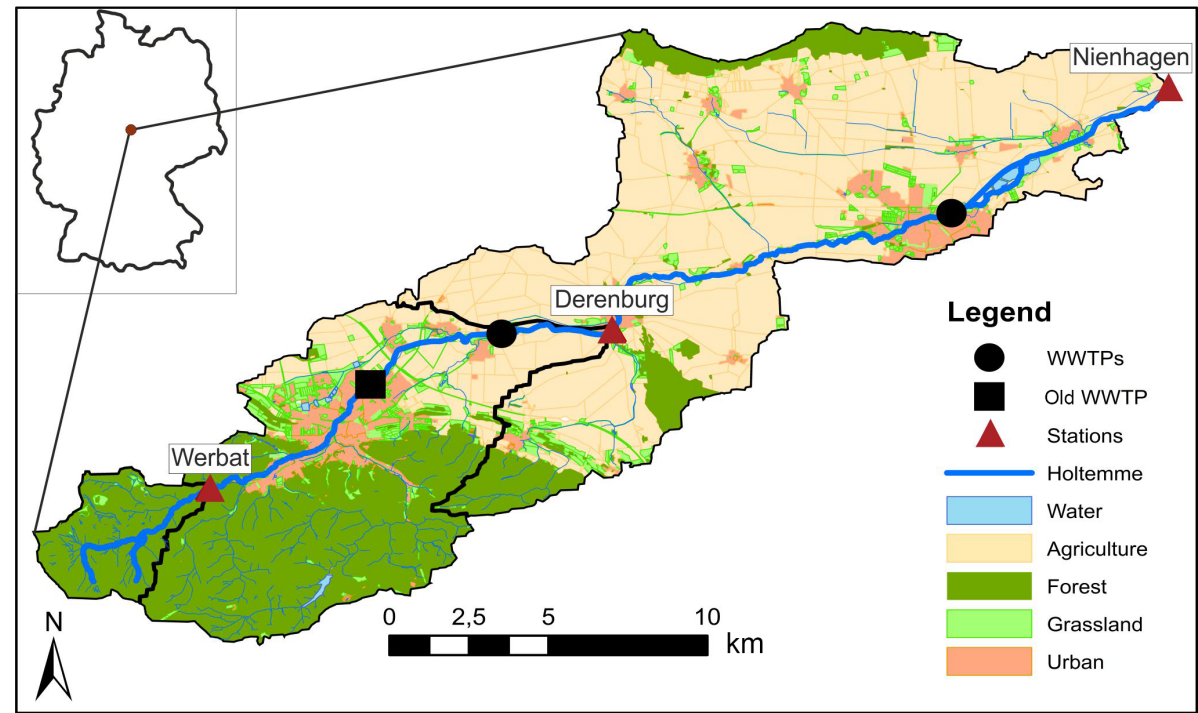

Figure 1. Map of the Holtemme catchment with the selected sampling locations. Map created from ATKIS data.

by Chernozems (Schuberth, 2008), representing one of the most fertile soils within Germany (Schmidt, 1995). Hence, the agricultural land use in this subcatchment is the highest $(81 \%)$ in comparison to the two upstream subcatchments (EEA, 2012).

\subsection{Nitrogen input}

The main $\mathrm{N}$ sources were quantified over time, assisting the data-based input-output assessment to address the three research questions regarding the $\mathrm{N}$ budgeting, effective TTs and $C-Q$ relationships in the catchment.

A recent investigation in the study catchment by Müller et al. (2018) showed that the major nitrate contribution stems from agricultural land use and the associated application of fertilizers. The quantification of this contribution is the $\mathrm{N}$ surplus (also referred to as agricultural surplus) that reflects $\mathrm{N}$ input that is in excess of crop and forage needs. For Germany there is no consistent dataset available for the $\mathrm{N}$ surplus that covers all land use types and is sufficiently resolved in time and space. Therefore, we combined the available agricultural $\mathrm{N}$ input (including atmospheric deposition) dataset with another dataset of atmospheric $\mathrm{N}$ deposition rates for the nonagricultural land.

The annual agricultural $\mathrm{N}$ input for the Holtemme catchment was calculated using two different datasets of agricultural $\mathrm{N}$ surplus across Germany provided by the University of Gießen (Bach and Frede, 1998; Bach et al., 2011). Surplus data $\left(\mathrm{kg} \mathrm{Nha}^{-1} \mathrm{a}^{-1}\right)$ were available at the federal state level for 1950-2015 and at the county level for 19952015, with an accuracy level of $5 \%$ (see Bach and Frede, 1998, for more details). We used the data from the overlapping time period (1995-2015) to downscale the statelevel data (state: Saxony-Anhalt) to the county level (county:
Harzkreis). Both (the state level and the aggregated county to state level) datasets show high correspondence with a correlation $\left(R^{2}\right)$ of 0.85 , but they differ slightly in their absolute values (by $6 \%$ of the mean annual values). The mean offset of $3.85 \mathrm{~kg} \mathrm{Nha}^{-1} \mathrm{a}^{-1}$ was subtracted from the federal state level data to yield the surplus in the county before 1995 .

Both of the above datasets account for the atmospheric deposition, but only on agricultural areas. For other nonagricultural areas (forest and urban landscapes), the $\mathrm{N}$ source stemming from atmospheric deposition was quantified based on datasets from the Meteorological Synthesizing Centre - West (MSC-W) of the European Monitoring and Evaluation Programme (EMEP). The underlying dataset consists of gridded fields of EU-wide wet and dry atmospheric $\mathrm{N}$ depositions from a chemical transport model that assimilates different observational records on atmospheric chemicals (e.g., Bartnicky and Benedictow, 2017; Bartnicky and Fagerli, 2006). This dataset is available with annual time-steps since 1995, and with data every 5 years between 1980 and 1995. Data between the 5-year time steps were linearly interpolated to obtain annual estimates of $\mathrm{N}$ deposition between 1980 and 1995. For years prior to 1980, we made use of global gridded estimates of atmospheric $\mathrm{N}$ deposition from the threedimensional chemistry-transport model (TM3) for the year 1860 (Dentener, 2006; Galloway et al., 2004). In absence of any other information, we performed a linear interpolation of the $\mathrm{N}$ deposition estimates between 1860 and 1980.

To quantify the net $\mathrm{N}$ fluxes to the soil nonagricultural land use types, the terrestrial biological $\mathrm{N}$ fixation had to be added to the atmospheric deposition. Based on a global inventory of terrestrial biological $\mathrm{N}$ fixation in natural ecosystems, Cleveland et al. (1999) estimated the mean uptake for temperate (mixed, coniferous or deciduous) forests and (tall/medium or short) grassland as $16.04 \mathrm{~kg} \mathrm{~N} \mathrm{ha}^{-1} \mathrm{a}^{-1}$ and 
Table 1. General information on the study area, including input-output datasets; $n$ - number of observations, $Q-$ discharge.

\begin{tabular}{lrrr}
\hline & Upstream & Midstream & Downstream \\
\hline$n Q$ & 16132 & - & 12114 \\
$n$ nitrate-N $\left(\mathrm{NO}_{3}-\mathrm{N}\right)$ & 646 & 631 & 770 \\
Period of $\mathrm{NO}_{3}-\mathrm{N}$ time series & $1972-2014$ & $1970-2011$ & $1976-2016$ \\
\hline Subcatchment area $\left(\mathrm{km}^{2}\right)$ & 15.06 & 88.50 & 165.22 \\
Cumulative catchment area $\left(\mathrm{km}^{2}\right)$ & 15.06 & 103.60 & 268.80 \\
Stream length $(\mathrm{km})$ & 1.5 & 19.3 & 24.4 \\
Mean topographic slope $\left({ }^{\circ}\right)$ & 9.82 & 7.52 & 2.55 \\
Mean topographic slope in nonforested area $\left(^{\circ}\right)$ & - & 3.2 & 1.9 \\
\hline Land use $($ Corine Land Cover; EEA, 2012) & & & \\
\hline Forest land use $(\%)$ & 100 & 56 & 11 \\
Urban land use $(\%)$ & - & 17 & 8 \\
Agricultural land use $(\%)$ & - & 27 & 81 \\
Fraction of agricultural area artificially drained $(\%)$ & - & 59.1 & 20.5 \\
\hline
\end{tabular}

$2.7 \mathrm{~kg} \mathrm{Nha}^{-1} \mathrm{a}^{-1}$, respectively. The atmospheric deposition and biological fixation for the different nonagricultural land uses were added to the agricultural $\mathrm{N}$ surplus to achieve the total $\mathrm{N}$ input per area. In contrast to the widely applied term net anthropogenic nitrogen input (NANI), we do not account for wastewater fluxes in the $\mathrm{N}$ input but rather focus on the diffuse $\mathrm{N}$ input and connected flow paths, where legacy accumulation and time lags between input and output potentially occur.

\subsection{Nitrogen output}

\subsubsection{Discharge and water quality time series}

Discharge and water quality observations were used to quantify the $\mathrm{N}$ load and to characterize the trajectory of $\mathrm{NO}_{3}-$ $\mathrm{N}$ concentrations and the $C-Q$ trajectories in the three subcatchments.

The data for water quality (biweekly to monthly) and discharge (daily) from 1970 to 2016 were provided by the LHW of Saxony-Anhalt. The biweekly to monthly sampling was done at gauging stations defining the three subcatchments. The datasets cover a wide range of instream chemical constituents including major ions, alkalinity, nutrients and in situ measured parameters $\left(\mathrm{pH}, \mathrm{O}_{2}\right.$, water temperature, electrical conductivity). As this study only focuses on $\mathrm{N}$ species, we restricted the selection of parameters to nitrate $\left(\mathrm{NO}_{3} ;\right.$ Fig. 2$)$, nitrite $\left(\mathrm{NO}_{2} ;\right.$ Fig. S1.2.2) and ammonium $\left(\mathrm{NH}_{4} ;\right.$ Fig. S1.2.1).

Discharge time series at daily timescales were measured at two of the water quality stations (upstream, downstream; Fig. 2). Continuous daily discharge series are required to calculate flow-normalized concentrations (see the following Sect. 2.3.2 for more details). To derive the discharge data for the midstream station and to fill measurement gaps at the other stations (2\% upstream, $3 \%$ downstream), we used simulations from a grid-based distributed mesoscale hydro- logical model mHM (Samaniego et al., 2010; Kumar et al., 2013). Daily mean discharge was simulated for the same time frame as the available measured data. We used a model setup similar to Müller et al. (2016) with robust results capturing the observed variability of discharge in the nearby studied catchments. We note that the discharge time series were used as weighting factors in the later analysis of flow-normalized concentrations. Consequently it is more important to capture the temporal dynamics than the absolute values. Nonetheless, we performed a simple bias correction method by applying the regression equation of simulated and measured values to reduce the simulated bias of modeled discharge. After this revision, the simulated discharges could be used to fill the gaps of measured data. The midstream station (Derenburg) for the water quality data is $5.6 \mathrm{~km}$ upstream of the next gauging station. Therefore, the nearest station (Mahndorf) with simulated and measured discharge data was used to derive the bias correction equation that was subsequently applied to correct the simulated discharge data at the midstream station, assuming the same bias between modeled and observed discharges at the gauging station.

\subsubsection{Weighted regression on time, discharge, and season (WRTDS) and wastewater correction}

The software package "Exploration and Graphics for RivEr Trends" (EGRET) in the $\mathrm{R}$ environment by Hirsch and DeCicco (2019) was used to estimate daily concentrations of $\mathrm{NO}_{3}-\mathrm{N}$ utilizing "Weighted Regressions on Time, Discharge, and Season" (WRTDS). The WRTDS method allows the interpolation of an irregularly sampled concentration to a regular series at a daily timescale using a flexible statistical representation for every day of the discharge record and proved to provide robust estimates (Hirsch et al., 2010; van Meter and Basu, 2017). In brief, a regression model based on the predictors discharge and time (to represent long-term 

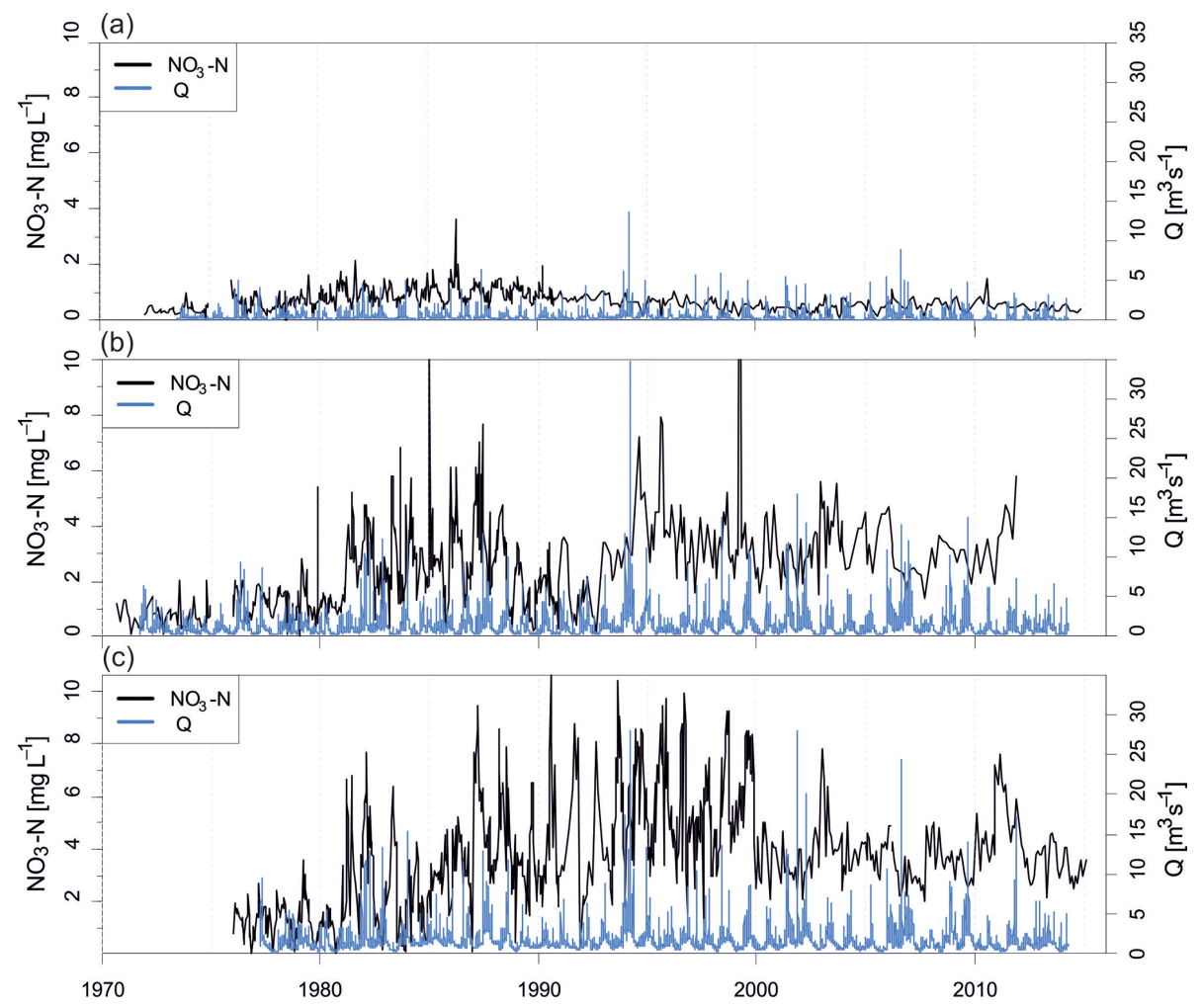

Figure 2. $\mathrm{NO}_{3}-\mathrm{N}$ concentration and discharge $(Q)$ time series: upstream (a), midstream (b) and downstream (c).

trend and seasonal component) is fitted for each day of the flow record with a flexible weighting of observations based on their time, seasonal and discharge "distance" (Hirsch et al., 2010). Results are daily concentrations and fluxes as well as daily flow-normalized concentrations and fluxes. Flow normalization uses the probability distribution of discharge of the specific day of the year from the entire discharge time series. More specifically, the flow-normalized concentration is the average of the same regression model for a specific day applied to all measured discharge values of the corresponding day of the year. While the non-flow-normalized concentrations are strongly dependent on the discharge, the flow-normalized estimations provide a more unbiased, robust estimate of the concentrations with a focus on changes in concentration and fluxes independent of interannual discharge variability (Hirsch et al., 2010). To account for uncertainty in the regression analysis of annual and seasonal flow-normalized concentration and fluxes, we used the block bootstrap method introduced by Hirsch et al. (2015). We derived the 5th and 95th percentile of annual flow-normalized concentration and flux estimates with a block length of $200 \mathrm{~d}$ and 10 replicates. The results are utilized to communicate uncertainty in both the $\mathrm{N}$ budgeting and the resulting TT estimation.

The study of Müller et al. (2018) indicated the dominance of $\mathrm{N}$ from diffuse sources in the Holtemme catchment but also stressed the impact of wastewater-borne nitrate during low-flow periods. Because our purpose was to balance and compare $\mathrm{N}$ input and outputs from diffuse sources only, the provided annual flux of total $\mathrm{N}$ from the two WWTPs was therefore used to correct flow-normalized fluxes and concentrations derived from the WRTDS assessment. We argue that the annual wastewater $\mathrm{N}$ flux is robust enough to correct the flow-normalized concentrations, but it does not allow for the correction of measured concentration data on a specific day. Both treatment plants provided snapshot samples of both $\mathrm{NO}_{3}-\mathrm{N}$ and total $\mathrm{N}$ fluxes to derive the fraction of $\mathrm{N}$ that is discharged as $\mathrm{NO}_{3}-\mathrm{N}$ into the stream. This fraction is $19 \%$ for the WWTP Halberstadt (384 measurements between January 2014 to July 2016) and $81 \%$ for Silstedt (eight measurements from February 2007 to December 2017). We argue that the fraction of $\mathrm{N}$ leaving as $\mathrm{NH}_{4}$, $\mathrm{NO}_{2}$ and $\mathrm{N}_{\text {org }}$ does not interfere with the $\mathrm{NO}_{3}-\mathrm{N}$ flux in the river due to the limited stream length and therefore nitrification potential of the Holtemme River impacted by wastewater (see also Sect. S1.2.3). We related the wastewater-borne $\mathrm{NO}_{3}-\mathrm{N}$ flux to the flow-normalized daily flux of $\mathrm{NO}_{3}-\mathrm{N}$ from the WRTDS method to get a daily fraction of wastewater $\mathrm{NO}_{3}-\mathrm{N}$ in the river that we used to correct the flownormalized concentrations. Note that this correction was applied to the midstream station from 1996 on, when the Silstedt treatment plant was taken to operation. In the downstream station, we additionally applied the correction from the Halberstadt treatment plant, renovated in the year 2000. Before 
that, we assume that wastewater-borne $\mathrm{N}$ dominantly leaves the treatment plants as $\mathrm{NH}_{4}-\mathrm{N}$ (see also Fig. S1.2.1).

Based on the daily resolved flow-normalized and wastewater-corrected concentration and flux data, descriptive statistical metrics were calculated on an annual timescale. Seasonal statistics of each year were also calculated for winter (December, January, February), spring (March, April, May), summer (June, July, August) and fall (September, October, November). Note that statistics for the winter season incorporate December values from the calendar year before.

Following Musolff et al. (2015, 2017), the ratio of $\mathrm{CV}_{C} / \mathrm{CV}_{Q}$ and the slope $(b)$ of the linear relationship between $\ln (C)$ and $\ln (Q)$ were used to characterize the export pattern and the export regimes of $\mathrm{NO}_{3}-\mathrm{N}$ along the three study catchments.

\subsection{Input-output assessment: nitrogen budgeting and effective travel times}

The input-output assessment is needed to estimate the retention potential for $\mathrm{N}$ in the catchment as well as to link temporal changes in the diffuse anthropogenic $\mathrm{N}$ inputs to the observed changes in the riverine $\mathrm{NO}_{3}-\mathrm{N}$ concentrations. The stream concentration of a given solute, e.g., as shown by Kirchner et al. (2000), is assumed at any time as the convolution of the TTD and the rainfall concentration throughout the past. This study applies the same principle for the $\mathrm{N}$ input as incoming time series that, when convolved with the TTD, yields the stream concentration time series. We selected a log-normal distribution function (with two parameters, $\mu$ and $\sigma$ ) as a convolution transfer function, based on a recent study by Musolff et al. (2017), who successfully applied this form of a transfer function to represent TTs. The two free parameters were obtained through optimization based on minimizing the sum of squared errors between observed and simulated $\mathrm{N}$ exports. The form of selected transfer function is in line with Kirchner et al. (2000) stating that exponential TTDs are unlikely at catchment scale, but rather a skewed, longtailed distribution would be likely. Note that we used the lognormal distribution as a transfer function between the temporal patterns of input ( $\mathrm{N}$ load per area) and flow-normalized concentrations on an annual timescale only and not as a fluxconservative transfer function. TTDs were inferred based on median annual and median seasonal flow-normalized concentrations and the corresponding $\mathrm{N}$ input estimates. To account for the uncertainties in the flow-normalized concentration input, we additionally derive TTDs for the confidence bands of the concentrations ( 5 th and 95th percentile) estimated through the bootstrap method (see Sect. 2.3.2 for more details). Here, we assumed that the width of the confidence bands provided for the annual concentrations also applies to the seasonal concentrations of the same year.

\section{Results}

\subsection{Input assessment}

In the period from 1950 to 2015, the Holtemme catchment received a cumulative diffuse $\mathrm{N}$ input (excluding the wastewater point sources) of $80055 \mathrm{t}$ with the majority of this associated with agriculture-related $\mathrm{N}$ application (74\%). Within the period when water quality data were available, the total sum is $63396 \mathrm{t}$ (1970-2015), with $76 \%$ agricultural contribution. The $\mathrm{N}$ input showed a remarkable temporal variability (see Fig. 6; purple, dashed line). From 1950 to 1976, the input was characterized by a strong increase (slope of linear increase $=2.4 \mathrm{~kg} \mathrm{Nha}^{-1} \mathrm{a}^{-1}$ per year) with a maximum annual, agricultural input of $132.05 \mathrm{~kg} \mathrm{Nha}^{-1} \mathrm{a}^{-1}$ (1976), which is 20 times the agricultural input in 1950. After more than 10 years of high but more stable inputs, the $\mathrm{N}$ surplus dropped dramatically with the peaceful reunification of Germany and the collapse of the established agricultural structures in East Germany (1989-1990; Gross, 1996). In the time period afterwards (1990-1995), the N surplus was only one-sixth $\left(20 \mathrm{~kg} \mathrm{Nha}^{-1} \mathrm{a}^{-1}\right)$ of the previous input. After another 8 years of increased agricultural inputs (1995-2003) of around $50 \mathrm{~kg} \mathrm{Nha}^{-1} \mathrm{a}^{-1}$, the input slowly decreased, with a mean slope of $-0.8 \mathrm{~kg} \mathrm{Nha}^{-1} \mathrm{a}^{-1}$ per year, but showed distinctive changes in the input between the years.

The median $\mathrm{N}$ input upstream $\left(53 \mathrm{ta}^{-1}\right)$ is less than $7 \%$ of the total catchment input $\left(760 \mathrm{ta}^{-1}\right)$. Hence, the input to the upstream area was only minor in comparison to the ones further downstream that are dominated by agriculture.

As land use change over the investigated period is negligible, the $\mathrm{N}$ input from biological fixation stayed constant.

\subsection{Output assessment}

\subsubsection{Discharge time series and WRTDS results on decadal statistics}

Discharge was characterized by a strong seasonality throughout the entire data record, which divided the year into a highflow season (HFS) during winter and spring, accounting for two-thirds of the annual discharge and a low-flow season (LFS) during summer and fall. Average discharge in the subcatchments is mainly a reflection of the strong spatial precipitation gradient across the study area being on the leeward side of the Harz Mountains. The upstream subcatchment contributed $21 \%$ of the median discharge measured at the downstream station (Table 2). The midstream station, representing the cumulated discharge signal from the up- and midstream subcatchments, accounted for $82 \%$ of the median annual discharge at the outlet. Although the upstream subcatchment had the highest specific discharge, the major fraction of total discharge $(61 \%)$ was generated in the midstream subcatchment. The seasonality in discharge was also dominated by this major midstream contribution, especially 


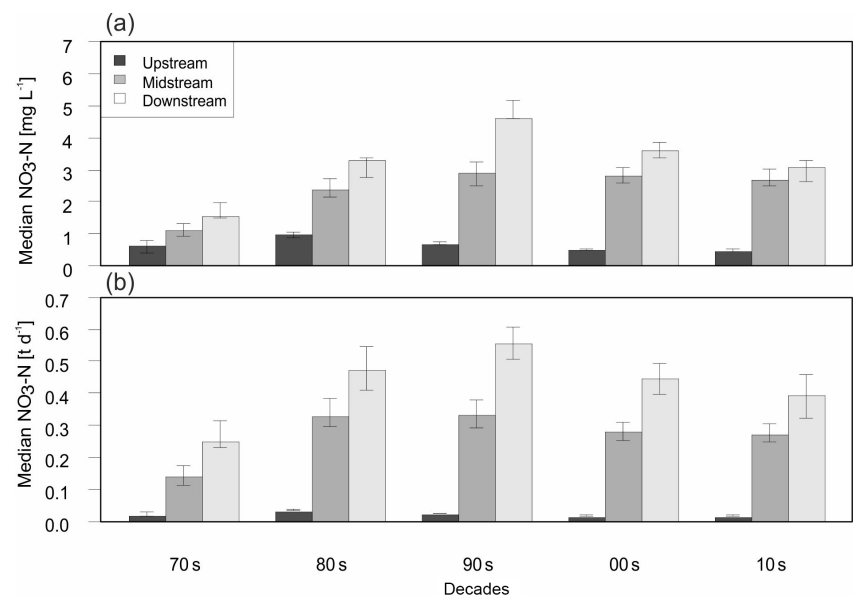

Figure 3. Flow-normalized median $\mathrm{NO}_{3}-\mathrm{N}$ concentrations (a) and $\mathrm{NO}_{3}-\mathrm{N}$ loads (b) for each decade of the time series and the three stations. Whiskers refer to the 5th and 95th percentiles of the WRTDS estimations.

during high-flow conditions, and vice versa: especially during HFSs, the median downstream contribution was less than $10 \%$, while during low-flow periods, the downstream contribution accounted for up to $33 \%$ (summer).

The flow-normalized $\mathrm{NO}_{3}-\mathrm{N}$ concentrations in each subcatchment showed strong differences in their overall levels and temporal patterns over the four decades (Fig. 3a; see also Figs. 2 and 6 for details). The lowest decadal concentration changes and the earliest decrease in concentrations were found in the pristine catchment. Median upstream concentrations were highest in the 80s (1987), with a reduction of the concentrations to about one-half in the latter decades. Over the entire period, the median upstream concentrations were smaller than $1 \mathrm{mgL}^{-1}$, so that the described changes are small compared to the $\mathrm{NO}_{3}-\mathrm{N}$ dynamics of the more downstream stations. High changes over time were observed in the two downstream stations with a tripling of concentrations between the 1970s and 1990s, when maximum concentrations were reached. While median concentrations downstream decreased slightly after this peak (1995/1996), the ones at the midstream station (peak: 1998) stayed constantly high. At the end of the observation period, at the outlet (downstream), the median annual concentrations did not decrease below $3 \mathrm{mg} \mathrm{L}^{-1}$ of $\mathrm{NO}_{3}-\mathrm{N}$, a level that was exceeded after the 1970s. The differences in $\mathrm{NO}_{3}-\mathrm{N}$ concentrations between the pristine upstream and the downstream station evolved from an increase by a factor of 3 in the 1970s to a factor of 7 after the 1980s.

Calculated loads (Fig. 3b) also showed a drastic change between the beginning and the end of the time series. The daily upstream load contribution was below $10 \%$ of the total annual export at the downstream station in all decades and then the estimates decreased from $9 \%$ (1970s) to $4 \%$ (2010s). The median daily load between the 1970s and 1990s tripled at the midstream station $\left(0.1\right.$ to $\left.0.3 \mathrm{td}^{-1}\right)$ and more than doubled downstream $\left(0.2\right.$ to $\left.0.5 \mathrm{t} \mathrm{d}^{-1}\right)$. In the $1990 \mathrm{~s}$, the Holtemme River exported on average more than $0.5 \mathrm{td}^{-1}$ of $\mathrm{NO}_{3}-\mathrm{N}$, which, related to the agricultural area in the catchment, translates into more than $3.1 \mathrm{~kg} \mathrm{~N} \mathrm{~km}^{-2} \mathrm{~d}^{-1}$ (maximum $13.4 \mathrm{~kg} \mathrm{Nha}^{-1} \mathrm{a}^{-1}$ in 1995).

\subsection{Input-output balance: $\mathbf{N}$ budget}

We jointly evaluated the estimated $\mathrm{N}$ inputs and the exported $\mathrm{NO}_{3}-\mathrm{N}$ loads to enable an input-output balance. This comparison on the one hand allowed for an estimation of the catchment's retention potential and on the other hand enabled us to estimate future exportable loads.

The load stemming from the most upstream, pristine catchment accounted for less than $10 \%$ of the exported riverine load at the outlet. To focus on the anthropogenic impacts, the data from the upstream station are not discussed on its own in the following. At the midstream station, a total sum of input of $16441 \mathrm{t}$ compared to $4109 \mathrm{t}$ of exported $\mathrm{NO}_{3}-\mathrm{N}$ for the overlapping time period of input and output was analyzed (1970-2011). The midstream subcatchment received $73 \%$ (Table 3 ) more $\mathrm{N}$ mass than it exported at the same time. Note that the exported $\mathrm{N}$ is not necessarily the $\mathrm{N}$ applied in the same period due to the temporal offset, as is discussed later in detail. With the assumption that $43 \%$ (agricultural $\mathrm{N}$ input of subcatchment $\mathrm{N}$ input) of the diffuse input resulted from agriculture, the subcatchment exported $616 \mathrm{~kg} \mathrm{Nha}^{-1}\left(537-719 \mathrm{~kg} \mathrm{Nha}^{-1}\right)$ from agricultural areas. The cumulated $\mathrm{N}$ input from the entire catchment (measured downstream) from 1976 to 2015 (overlapping time of input and output) was $53437 \mathrm{t}$, while the riverine export in the same time frame was only $12 \%\left(6 \mathrm{~kg} \mathrm{~N} \mathrm{ha}^{-1} \mathrm{a}^{-1} ; 11 \%-\right.$ $14 \%$ ), implying an agricultural export of $370 \mathrm{~kg} \mathrm{Nha}^{-1}$ (325-415 $\mathrm{kg} \mathrm{N} \mathrm{ha}^{-1}$; Fig. 4). This mass discrepancy between input and output translates into a retention rate in the entire Holtemme catchment of $88 \%(86 \%-89 \%)$. In relation to the entire subcatchment area (not only agricultural land use), the annual retention rate of $\mathrm{NO}_{3}-\mathrm{N}$ was around $28 \mathrm{~kg} \mathrm{Nha}^{-1} \mathrm{a}^{-1}$ $\left(27-30 \mathrm{~kg} \mathrm{Nha}^{-1} \mathrm{a}^{-1}\right)$ in the midstream subcatchment and $59 \mathrm{~kg} \mathrm{Nha}^{-1} \mathrm{a}^{-1}\left(59-59 \mathrm{~kg} \mathrm{Nha}^{-1} \mathrm{a}^{-1}\right)$ in the flatter and more intensively cultivated downstream subcatchment.

\subsection{Effective TTs of N}

We approximated the effective TTs for all seasonal $\mathrm{NO}_{3}-\mathrm{N}$ concentration trajectories at the midstream and downstream stations by fitting the log-normal TTDs (Fig. 5; Table 4). Note that the upstream station was not used here due to the lack of temporally resolved input data on the atmospheric $\mathrm{N}$ deposition (estimated linear input increase between 1950 and 1979). In general, the optimized distributions were able to sufficiently capture the time lag and smoothing between the input and output concentrations $\left(R^{2} \geq 0.72\right.$; see also Figs. S2.1 and S2.2). Systematic differences between stations 
Table 2. Descriptive statistics on discharge at the three observation points; LFS - low-flow season (June-November), HFS - high-flow season (December-May).

\begin{tabular}{lrrr}
\hline & Upstream & Midstream & Downstream \\
\hline Median discharge $\left(\mathrm{m}^{3} \mathrm{~s}^{-1}\right)$ & 0.23 & 0.9 & 1.1 \\
Mean specific discharge $\left(\mathrm{mm} \mathrm{a}^{-1}\right)$ & 768 & 411 & 178 \\
LFS subcatchment contribution (\%) & 17 & 53 & 30 \\
HFS subcatchment contribution (\%) & 21 & 69 & 10 \\
\hline
\end{tabular}

Table 3. Nitrogen retention potentials derived for the midstream and downstream subcatchment based on flow-normalized fluxes. Numbers in brackets refer to the 5th and 95th percentiles of the WRTDS flux estimation.

\begin{tabular}{lll}
\hline & Midstream & Downstream \\
\hline Retention cumulative $(\%)$ & $75(71-78)(\mathrm{Up}-+$ midstream $)$ & $88(86-89)(\mathrm{Up}-+$ mid- + downstream) \\
Retention subcatchment $(\%)$ & $73(68-76)$ & $94(94-95)$ \\
Retention per year $\left(\mathrm{N} \mathrm{kg} \mathrm{a}^{-1}\right)$ & $251589(235778-263833)$ & $917823(968085-979679)$ \\
Retention per area $\left(\mathrm{N} \mathrm{kg} \mathrm{a}^{-1} \mathrm{ha}^{-1}\right)$ & $28.43(26.64-29.81)$ & $58.82(58.60-59.30)$ \\
\hline
\end{tabular}

and seasons can be observed, best represented by the mode of the distributions (peak TTs). The average deviation between the best- and worst-case estimation of the fitted TTDs from their respective average value was only $4 \%$ with respect to the mode of the distributions (Table 4).

The TTDs for all seasons taken together showed longer TTs for the midstream in comparison to the downstream station. The comparison of the TTD modes for the different seasons at the midstream station showed distinctly differing peak TTs between 11 years (spring) and 22 years (fall), which represented a doubling of the peak TT. The fastest times appeared in the HFSs while modes of the TTDs appeared longer in the LFSs. Note that the shape factor $\sigma$ of the effective TTs also changed systematically: the HFS spring exhibited a higher shape factor than those of the other seasons. This refers to a change in the coefficient of variation of the distributions at the midstream station from 0.6 in spring to 0.2 in fall.

The modes of the fitted distributions for the downstream station for each season were shorter than the ones at the midstream station. The mode of the TTs ranged between 7 years (spring) and 15 years (winter, fall). The shape factors of the fitted TTDs ranged between 0.8 (spring) and 0.3 (summer) for the downstream station. In summary, HFS spring in both subcatchments had shorter TTDs than the other seasons and the midstream subcatchment showed longer TTDs than downstream.

\subsection{Seasonal $\mathrm{NO}_{3}-\mathrm{N}$ concentrations and $\mathrm{C}-Q$ relationships over time}

As described above, the Holtemme catchment showed a pronounced seasonality in discharge conditions, producing the HFS in December-May (winter + spring) and the LFS in June-November (summer + fall). Therefore, changes in the seasonal concentrations of $\mathrm{NO}_{3}-\mathrm{N}$ also reflect in the annual $C-Q$ relationship. Analyzing the changing seasonal dynamics therefore provide a deeper insight into $\mathrm{N}$ trajectories in the Holtemme catchment.

In the pristine upstream catchment, no temporal changes in the seasonal differences of riverine $\mathrm{NO}_{3}-\mathrm{N}$ concentrations could be found (Fig. 6a). Also the $C-Q$ relationship (Fig. 6d) showed a steady pattern (moderate accretion), with the highest concentrations in the HFSs, i.e., winter and spring. The ratio of $\mathrm{CV}_{C} / \mathrm{CV}_{Q}$ indicates a chemostatic export regime and changed only marginally (amplitude of 0.2 ) over time.

At the midstream station (Fig. 6b), the early 1970s showed an export pattern with highest concentration during HFSs similar to the upstream catchment, but with a general increase in concentrations from 1970 to 1995. During the 1980s, the increase in concentrations in the HFS was faster than in the LFS, which changed the $C-Q$ pattern to a strongly positive one $\left(b_{\max }=0.42,1987\right.$; red to orange symbols in Fig. 6e). This development was characterized by a tripling of intra-annual amplitudes $\left(C_{\text {spring }}-C_{\text {fall }}\right)$ of up to $2.4 \mathrm{mg} \mathrm{L}^{-1}$ (1987). With a lag of around 10 years, in the 1990s the LFSs also exhibit a strong increase in concentrations $\left(C_{\max }=3.1 \mathrm{mg} \mathrm{L}^{-1}, 1998\right.$, Fig. 6b). The midstream concentration time series shows bimodality. The $C-Q$ relationships (Fig. 6e) evolved from an intensifying accretion pattern in the 1970s and 1980s (red to orange symbols in Fig. 6e) to a constant pattern between $C$ and $Q$ in the 1990 s and afterwards (yellow symbols). The $\mathrm{CV}_{C} / \mathrm{CV}_{Q}$ increased during the 1970s and strongly decreased afterwards by 0.4 between 1984 and 1995, showing a trajectory starting from a more chemostatic to a chemodynamic and then back to a chemostatic export regime.

At the downstream station (Fig. 6c) the concentrations in the HFSs were found to be comparable to the ones observed 


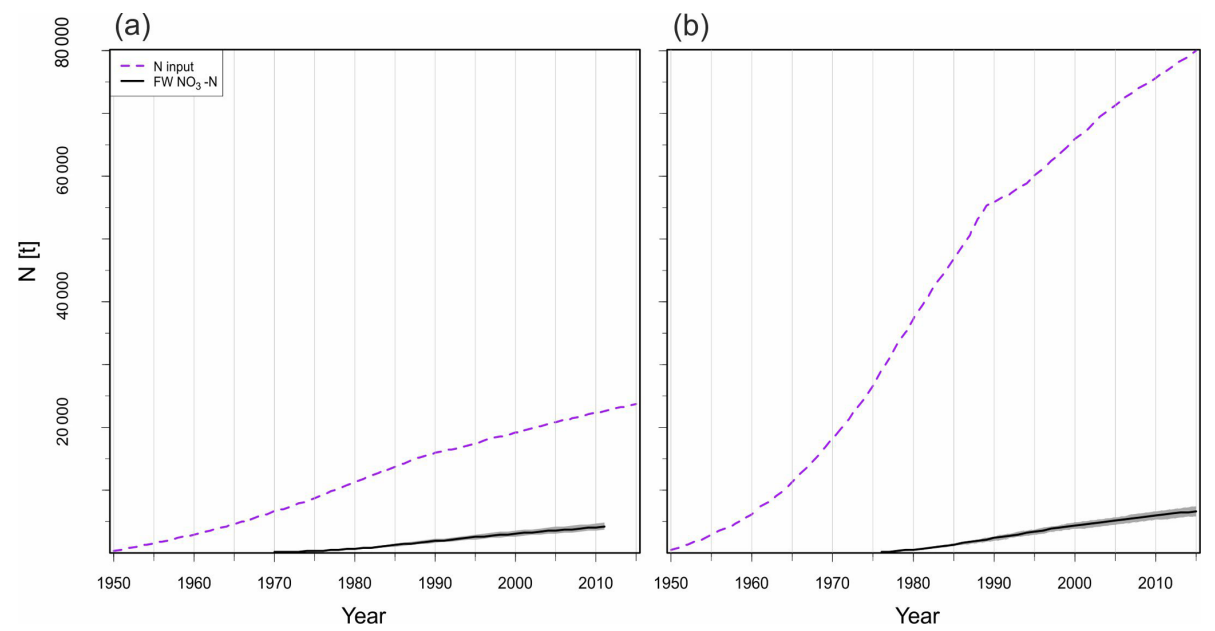

Figure 4. Cumulative annual diffuse $\mathrm{N}$ inputs to the catchment and measured cumulative $\mathrm{NO}_{3}-\mathrm{N}$ exported load over time for midstream (a) and downstream (b) stations. Shaded grey confidence bands refer to the 5th and 95th percentile of the WRTDS flux estimation.

Table 4. Best-fit parameters of the log-normal TTDs for the $\mathrm{N}$ input and output responses. Parameters in brackets are derived by using the 5 th and 95th percentiles of the bootstrapped flow-normalized concentration estimates.

\begin{tabular}{llrrrrr}
\hline & Parameter & All seasons & Winter & Spring & Summer & Fall \\
\hline \multirow{2}{*}{ Midstream } & $\mu$ & $3.0(3.0-3.1)$ & $3.0(3.0-3.1)$ & $2.7(2.7-2.7)$ & $3.0(3.0-3.1)$ & $3.1(3.1-3.2)$ \\
& $\sigma$ & $0.3(0.3-0.4)$ & $0.3(0.3-0.4)$ & $0.6(0.6-0.6)$ & $0.3(0.3-0.4)$ & $0.2(0.1-0.3)$ \\
& Mode (years) & $18.5(16.7-20.5)$ & $17.8(16.0-20)$ & $11.1(10.3-10.3)$ & $18.9(17.1-20.8)$ & $21.9(20.8-23.9)$ \\
& $R^{2}$ & $0.93(0.91-0.91)$ & $0.88(0.83-0.86)$ & $0.81(0.72-0.80)$ & $0.91(0.90-0.90)$ & $0.87(0.86-0.86)$ \\
\hline \multirow{2}{*}{ Downstream } & $\mu$ & $2.8(2.8-2.9)$ & $3.0(3.0-3.0)$ & $2.6(2.7-2.7)$ & $2.7(2.7-2.7)$ & $2.9(2.9-2.9)$ \\
& $\sigma$ & $0.6(0.5-0.6)$ & $0.5(0.5-0.5)$ & $0.8(0.7-0.8)$ & $0.3(0.2-0.3)$ & $0.5(0.5-0.5)$ \\
& Mode (years) & $12.4(12.1 .-13.1)$ & $15.1(14.7-16.4)$ & $7.4(7.9-8.3)$ & $13.8(13.6-14.2)$ & $14.7(14.1-14.9)$ \\
& $R^{2}$ & $0.94(0.89-0.92)$ & $0.92(0.82-0.92)$ & $0.84(0.83-0.92)$ & $0.90(0.84-0.88)$ & $0.81(0.72-0.77)$ \\
\hline
\end{tabular}

at the midstream station. As seen at the midstream station, the $\mathrm{N}$ concentrations during the LFSs peaked with a delay compared to those of the HFSs. The resulting intra-annual amplitude showed a maximum of $2.4 \mathrm{mg} \mathrm{L}^{-1}$ in the $1980 \mathrm{~s}$ (1983-1984), with strongly positive $C-Q$ patterns $\left(b_{\max }=\right.$ 0.4, 1985; red symbols in Fig. 6f). In contrast to the bimodal concentration trends in the mid- and downstream HFSs, the LFSs downstream showed an unimodal pattern peaking around 1995-1996 with concentrations above $6 \mathrm{mg} \mathrm{L}^{-1}$ $\mathrm{NO}_{3}-\mathrm{N}\left(C_{\max }=6.9 \mathrm{mg} \mathrm{L}^{-1}\right)$. In the $1990 \mathrm{~s}$, the concentrations in the LFSs were higher than those noticed in the HFSs, causing a switch to a dilution $C-Q$ pattern (orange symbols in Fig. 6f). Due to the strong decline of LFS concentrations after 1995 (Fig. 6c), the dilution pattern evolved to a constant $C-Q$ pattern (yellow symbols in Fig. 6f) from the 2000s onward. After an initial phase with chemostatic conditions (1970s), the $\mathrm{CV}_{C} / \mathrm{CV}_{Q}$ strongly increased to a chemodynamic export regime in the $1980 \mathrm{~s}\left(\max . \mathrm{CV}_{C} / \mathrm{CV}_{Q}=0.8\right.$, 1984). Later on $\mathrm{CV}_{C} / \mathrm{CV}_{Q}$ declined by 0.8 between 1984 and $2001\left(\min . \mathrm{CV}_{C} / \mathrm{CV}_{Q}=0.03\right)$, which indicates the $C-$
$Q$ trajectory is coming back to a chemostatic export nitrate regime.

\section{Discussion}

\subsection{Catchment-scale $\mathrm{N}$ budgeting}

Based on the calculated budgets of $\mathrm{N}$ inputs and riverine $\mathrm{N}$ outputs for the three subcatchments within the Holtemme catchment, we discuss here differences between the subcatchments and potential main reasons for the missing part in the $\mathrm{N}$ budget: (1) permanent $\mathrm{N}$ removal by denitrification or (2) the buildup of $\mathrm{N}$ legacies.

The $\mathrm{N}$ load stemming from the most upstream, pristine catchment accounted for less than $10 \%$ of the exported annual load over the entire study period. This minor contribution can be attributed to the lack of agricultural and urban land use as dominant sources for $\mathrm{N}$. Consequently, the $\mathrm{N}$ export from the upstream subcatchment was dominantly controlled by $\mathrm{N}$ inputs from atmospheric deposition and biological fixation. 


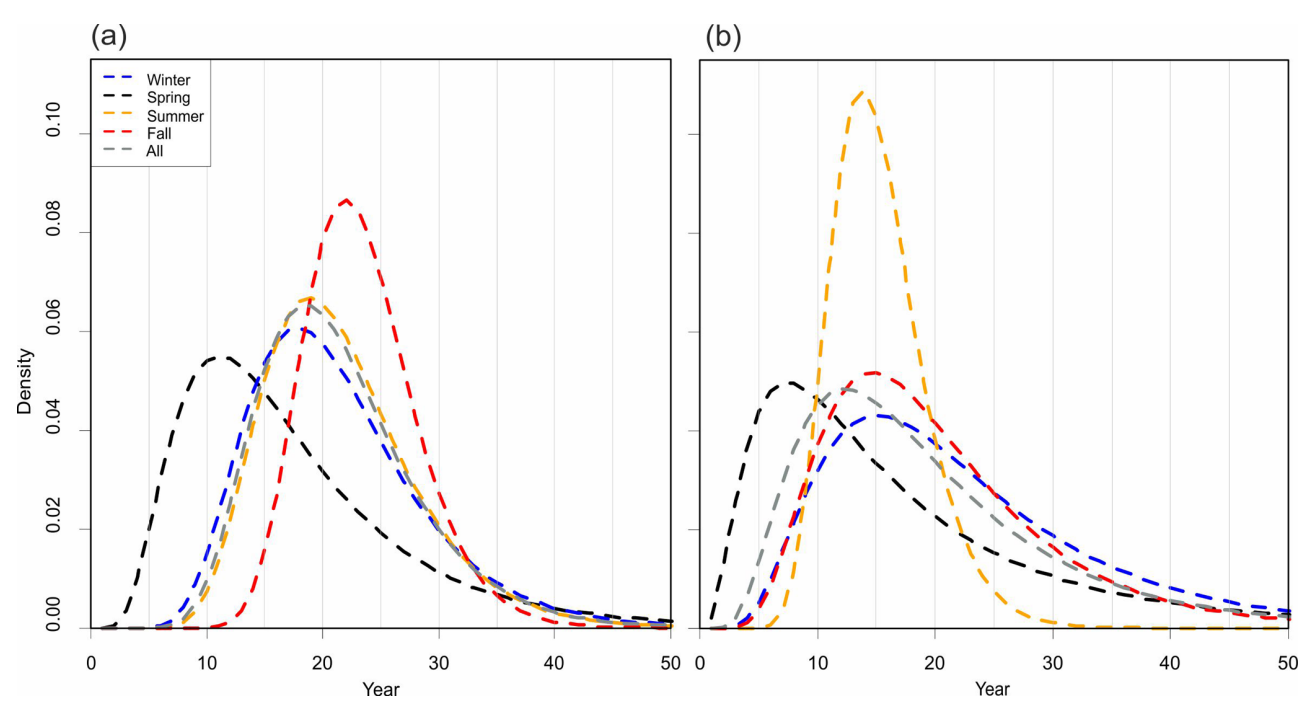

Figure 5. Seasonal variations in the fitted log-normal distributions of effective travel times between nitrogen input and output responses for midstream (a) and downstream (b) stations.

The total input over the whole catchment area was quantified as more than $53000 \mathrm{tN}(1976-2015)$ and, compared to the respective output over the same time period, yielded export rates of $25 \%(22 \%-29 \%)$ at the midstream and $12 \%$ $(11 \%-14 \%)$ at the downstream station (Table 3), respectively. There can be several reasons for the difference in export rates between the two subcatchments. The most likely ones are due to differences in discharge, topography and denitrification capacity among the subcatchments, which are discussed in the following.

Load export of $\mathrm{N}$ from agricultural catchments is assumed to be mainly discharge-controlled (Basu et al., 2010). Many solutes show a lower variance in concentrations compared to the variance in streamflow, which makes the flow variability a strong surrogate for load variability (Jawitz and Mitchell, 2011). This can also be seen in the Holtemme catchment, which evolved over time to a more chemostatic export regime with high $\mathrm{N}$ loads (Fig. 6b). The highest $\mathrm{N}$ export and lowest retention were observed in the midstream subcatchment, where the overall highest discharge contribution can be found.

Besides discharge quantity, we argue that the midstream subcatchment favors a more effective export of $\mathrm{NO}_{3}-\mathrm{N}$. The higher percentage of artificial drainage by tiles and ditches (59\% vs. $21 \%$; Sect. S1.1) as well as the steeper terrain slopes $\left(3.2^{\circ}\right.$ vs. $\left.1.9^{\circ}\right)$ in the nonforested area of the midstream catchment promotes rapid, shallow subsurface flows. These flow paths can more directly connect agricultural $\mathrm{N}$ sources with the stream and in turn cause elevated instream $\mathrm{NO}_{3}-\mathrm{N}$ concentrations (Yang et al., 2018a). In addition, the steeper surface topography suggests a deeper vertical infiltration (Jasechko et al., 2016) and therefore a wider range of flow paths of different ages than those observed in the flatter terrain areas, and vice versa: fewer drainage installations, a flatter terrain and thus in general shallower flow paths may decrease the $\mathrm{N}$ export efficiency (increase the retention) potential downstream.

The only process able to permanently remove $\mathrm{N}$ input from the catchment is denitrification in soils, aquifers (Seitzinger et al., 2006; Hofstra and Bouwman, 2005), and at the streamaquifer interface such as in the riparian (Vidon and Hill, 2004; Trauth et al., 2018) and hyporheic zones (Vieweg et al., 2016). As the riverine exports are signals of the catchment or subcatchment processes, integrated in time and space, separating a buildup of an $\mathrm{N}$ legacy from a permanent removal via denitrification is difficult. A clear separation of these two key processes, however, would be important for decision makers as both have different implications for management strategies and different future impacts on water quality. Even if groundwater quality measurements that indicate denitrification were available, using this type of local information for an effective catchment-scale estimation of $\mathrm{N}$ removal via denitrification would be challenging (Green et al., 2016; Otero et al., 2009; Refsgaard et al., 2014). Therefore, we discuss the denitrification potential in the soils and aquifers of the Holtemme catchment based on a local isotope study and a literature review of studies in similar settings. A strong argument against a dominant role of denitrification is provided by Müller et al. (2018) for the study area. On the basis of a monitoring of nitrate isotopic compositions in the Holtemme River and in tributaries, Müller et al. (2018) stated that denitrification played no or only a minor role in the catchment. However, we still see the need to carefully check the potential of denitrification to explain the input-output imbalance considering other studies.

If $88 \%$ of the $\mathrm{N}$ input ( $53437 \mathrm{t}$, dominantly agricultural input) to the catchment between 1976 and 2015 (39 years) were denitrified in the soils of the agricultural area $\left(161 \mathrm{~km}^{2}\right)$, it 
(a)

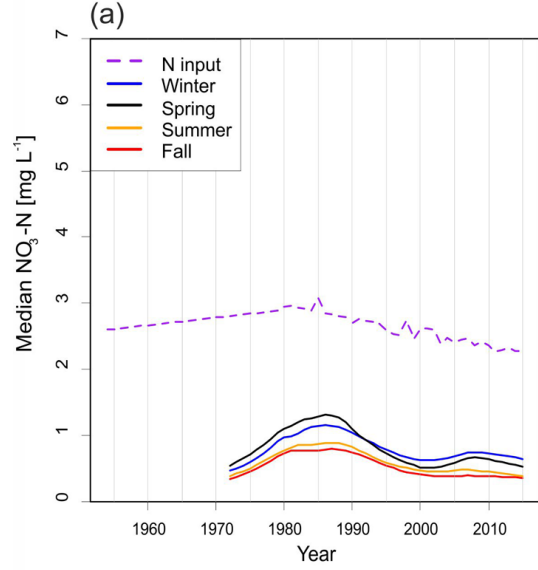

(d)

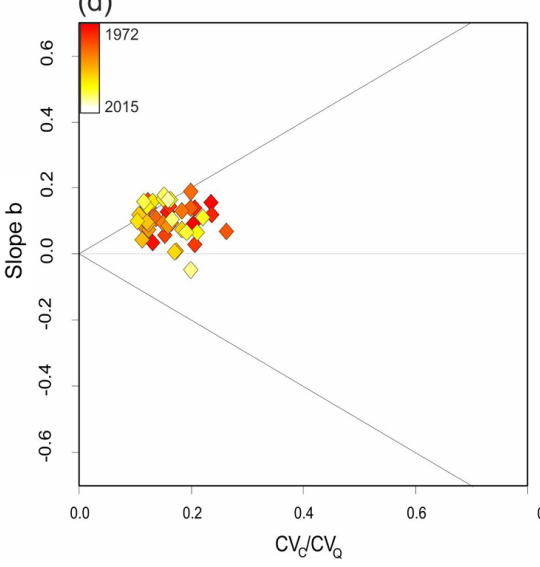

(b)

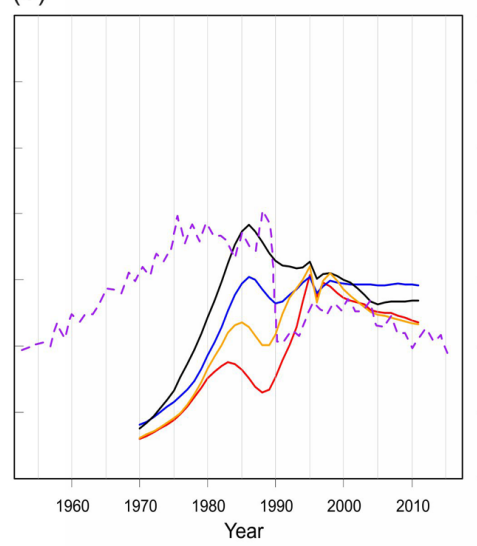

(e)

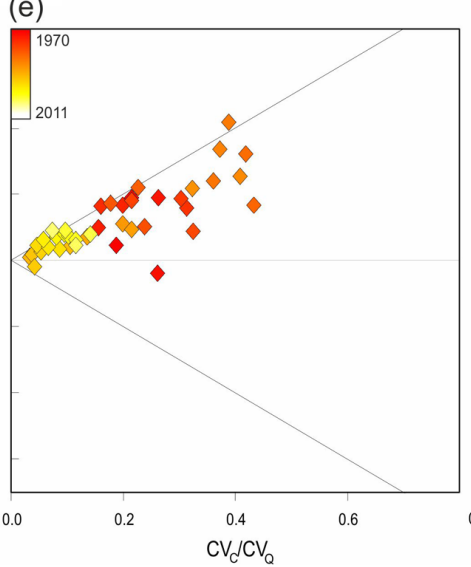

(c)

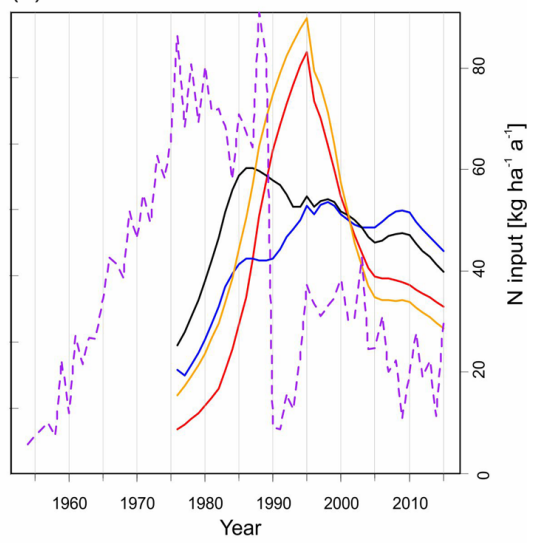

(f)

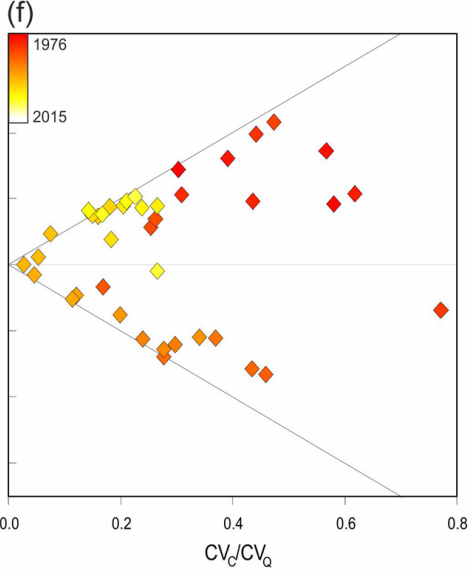

Figure 6. Annual $\mathrm{N}$ input (referring to the whole catchment, second $y$ axis) to the catchment and measured median $\mathrm{NO}_{3}-\mathrm{N}$ concentrations in the stream (first $y$ axis) over time at three different locations: upstream (a, d), midstream (b, e), downstream (c, f). Lower panels show plots of slope $b$ vs. $\mathrm{CV}_{C} / \mathrm{CV}_{Q}$ for $\mathrm{NO}_{3}-\mathrm{N}$ for the three subcatchments following the classification scheme provided in Musolff et al. (2015). The $x$ axis gives the coefficient of variation of concentrations $(C)$ relative to the coefficient of variation of discharge $(Q)$. The $y$ axis gives the slope b of the linear $\ln (C)-\ln (Q)$ relationship. Colors indicate the temporal evolution from 1970 to 2015 along a gradient from red to yellow.

would need a rate of $74.9 \mathrm{~kg} \mathrm{Nha}^{-1} \mathrm{a}^{-1}$. Considering the derived TTs, denitrification of the convolved input would need a slightly lower rate $\left(66.7 \mathrm{~kg} \mathrm{~N} \mathrm{ha}^{-1} \mathrm{a}^{-1}, 1976-2015\right)$. Denitrification rates in soils for Germany (NLfB, 2005) have been reported to range between 13.5 and $250 \mathrm{~kg} \mathrm{Nha}^{-1} \mathrm{a}^{-1}$, with rates larger than $50 \mathrm{~kg} \mathrm{Nha}^{-1} \mathrm{a}^{-1}$ may be found in carbonrich and waterlogged soils in the riparian zones near rivers and in areas with fens and bogs (Kunkel et al., 2008). As water bodies and wetlands make up only $1 \%$ of the catchment's land use (Fig. 1; EEA, 2012), and consequently the extent of waterlogged soils is negligible, denitrification rates larger than $50 \mathrm{~kg} \mathrm{~N} \mathrm{ha}^{-1} \mathrm{a}^{-1}$ are highly unlikely. In a global study, Seitzinger et al. (2006) assumed a rate of $14 \mathrm{~kg} \mathrm{~N} \mathrm{ha}^{-1} \mathrm{a}^{-1}$ as denitrification for agricultural soils. With this rate only $19 \%$ of the retained ( $88 \%$ ) study catchment's $\mathrm{N}$ input can be denitrified. On the basis of a simulation with the modeling framework GROWA-WEKU-MEPhos, Kuhr et al. (2014) estimate very low to low denitrification rates, of $9-13 \mathrm{~kg} \mathrm{~N} \mathrm{ha}^{-1} \mathrm{a}^{-1}$, for the soils of the Holtemme catchment. Based on the above discussion we find for our study catchment, the denitrification in the soils, including the riparian zone, may partly explain the retention of $\mathrm{NO}_{3}-\mathrm{N}$, but there is unlikely to be a single explanation for the observed imbalance between input and output.

Regarding the potential for denitrification in groundwater, the literature provides denitrification rate constants of a firstorder decay process between 0.01 and $0.56 \mathrm{a}^{-1}$ (van Meter et al., 2017b; van der Velde et al., 2010; Wendland et al., 2005). We derived the denitrification constant by distributing the input according to the fitted log-normal distribution of TTs, assuming a first-order decay along the flow paths (Kuhr et al., 2014; Rode et al., 2009; van der Velde, 2010). The denitrification of the $88 \%$ of input mass would require a rate constant of $0.14 \mathrm{a}^{-1}$. This constant is in the range of values reported by the abovementioned modeling studies. However, in a regional evaluation of groundwater quality, Hannappel et 
al. (2018) provide strong evidence that denitrification in the groundwater of the Holtemme catchment is not a dominant retention process. More specifically, Hannappel et al. (2018) assess denitrification in over 500 wells in the federal state of Saxony-Anhalt for nitrate, oxygen, iron concentrations and redox potential and connect the results to the hydrogeological units. Within the hard rock aquifers that are present in our study area, only $0 \%-16 \%$ of the wells showed signs of denitrification. Taking together the local evidence from the nitrate isotopic composition (Müller et al., 2018), the regional evidence from groundwater quality (Hannappel et al., 2018), and the rates provided in literature for soils and groundwater, we argue that the role of denitrification in groundwater is unlikely to explain the observed imbalance between $\mathrm{N}$ input and output.

Lastly, assimilatory $\mathrm{NO}_{3}$ uptake in the stream may be a potential contributor to the difference between input and output. But even with maximal $\mathrm{NO}_{3}$ uptake rates as reported by Mulholland et al. (2004; $0.14 \mathrm{~g} \mathrm{~N} \mathrm{~m}^{-2} \mathrm{~d}^{-1}$ ) or Rode et al. (2016; max. $0.27 \mathrm{~g} \mathrm{~N} \mathrm{~m}^{-2} \mathrm{~d}^{-1}$, estimated for a catchment adjacent to the Holtemme), the annual assimilatory uptake in the river would be a minor removal process, estimated to contribute only $3 \%$ of the $88 \%$ discrepancy between input and output. According to the rates reported by Mulholland et al. (2008; $\max .0 .24 \mathrm{~g} \mathrm{~N} \mathrm{~m}^{-2} \mathrm{~d}^{-1}$ ), the Holtemme River would need an area 45 times larger to be able to denitrify the retained $\mathrm{N}$. Therefore denitrification in the stream can be excluded as a dominant removal process.

In summary, the precise differentiation between the accumulation of an $\mathrm{N}$ legacy and removal by denitrification cannot be fully resolved on the basis of the available data. Also a mix of both may account for the missing $88 \%$ (86\%-89\%, downstream) or $75 \%$ (71\%-78\%, midstream) in the $\mathrm{N}$ output. Input-output assessments with time series from different catchments, as presented in van Meter and Basu (2017), covering a larger variety of catchment characteristics, hold promise for an improved understanding of the controlling parameters and dominant retention processes.

The fact that current $\mathrm{NO}_{3}$ concentration levels in the Holtemme River still show no clear sign of a significant decrease calls for a continuation of the $\mathrm{NO}_{3}$ concentration monitoring, best extended by additional monitoring in soils and groundwater. Despite strong reductions in agricultural $\mathrm{N}$ input since the 1990s, the annual $\mathrm{N}$ surplus (e.g., $818 \mathrm{ta}^{-1}$, 2015) is still much higher than the highest measured export $\left(\operatorname{load}_{\max }=216 \mathrm{ta}^{-1}, 1995\right)$ from the catchment. Hence, the difference between input and output is still high with a mean factor of 6 during the past 10 years (mean factor of 7 with the shifted input according to 12 years of TT). Consequently, either the legacy of $\mathrm{N}$ in the catchment keeps growing instead of getting depleted or the system relies on a potentially limited denitrification capacity. Denitrification may irreversibly consume electron donors like pyrite for autolithotrophic denitrification or organic carbon for heterotrophic denitrification (Rivett et al., 2008).
Based on the analyses and literature research, there is evidence but no proof of the fate of missing $\mathrm{N}$, although a directed water quality management would need a clearer differentiation between $\mathrm{N}$ mass that is stored or denitrified. However, neither tolerating the growing buildup of legacies nor relying on finite denitrification represents sustainable and adapted agricultural management practices. Hence, future years will also face increased $\mathrm{NO}_{3}-\mathrm{N}$ concentrations and loads exported from the Holtemme catchment.

\subsection{Linking effective TTs, concentrations and $C-Q$ trajectories with $\mathrm{N}$ legacies}

Based on our data-driven analyses, we propose the following conceptual model (Fig. 7) for $\mathrm{N}$ export from the Holtemme catchment, which is able to plausibly connect and synthesize the available data and findings on TTs, concentration trajectories and $C-Q$ relationships and allows for a discussion on the type of $\mathrm{N}$ legacy.

Over the course of a year, different subsurface flow paths are active, which connect different subsurface $\mathrm{N}$ source zones with different source strength (in terms of concentration and flux) to streams. These flow paths transfer water and $\mathrm{NO}_{3}-\mathrm{N}$ to streams, predominantly from shallower parts of the aquifer when water tables are high during HFSs and exclusively from deeper groundwater during low flows in LFSs (Rozemeijer and Broers, 2007; Dupas et al., 2016; Musolff et al., 2016). This conceptual model allows us to explain the observed intra-annual concentration patterns and the distinct clustering of TTs into low-flow and high-flow conditions. Furthermore, it can explain the mobilization of nutrients from spatially distributed $\mathrm{NO}_{3}-\mathrm{N}$ sources by temporally varying flow-generating zones (Basu et al., 2010). Spatial heterogeneity of solute source zones can be a result of downward migration of the dominant $\mathrm{NO}_{3}-\mathrm{N}$ storage zone in the vertical soil-groundwater profile (Dupas et al., 2016). Moreover, a systematic increase in the water age with depths would, if denitrification in groundwater takes place uniformly, lead to a vertical concentration decrease. Based on the stable hydroclimatic conditions without changes in land use, topography or the river network during the observation period, long-term changes in flow paths in the catchment are unlikely. Assuming that flow contributions from the same depths do not change between the years, the observed decadal changes in the seasonal concentrations cannot be explained by a stronger imprint of denitrification with increasing water age. Under such conditions one would expect a more steady seasonality in concentrations and $C-Q$ patterns over time with $\mathrm{NO}_{3}-\mathrm{N}$ concentrations that are always similarly high in HFSs and similarly low in LFSs, which we do not see in the data. Additionally, previous findings have indicated no or only a minor role of denitrification in the catchment (Hannappel et al., 2018; Kunkel et al., 2008; Müller et al., 2018). In line with Dupas et al. (2016) we instead argue that the vertical migration of a temporally changing $\mathrm{NO}_{3}-\mathrm{N}$ 


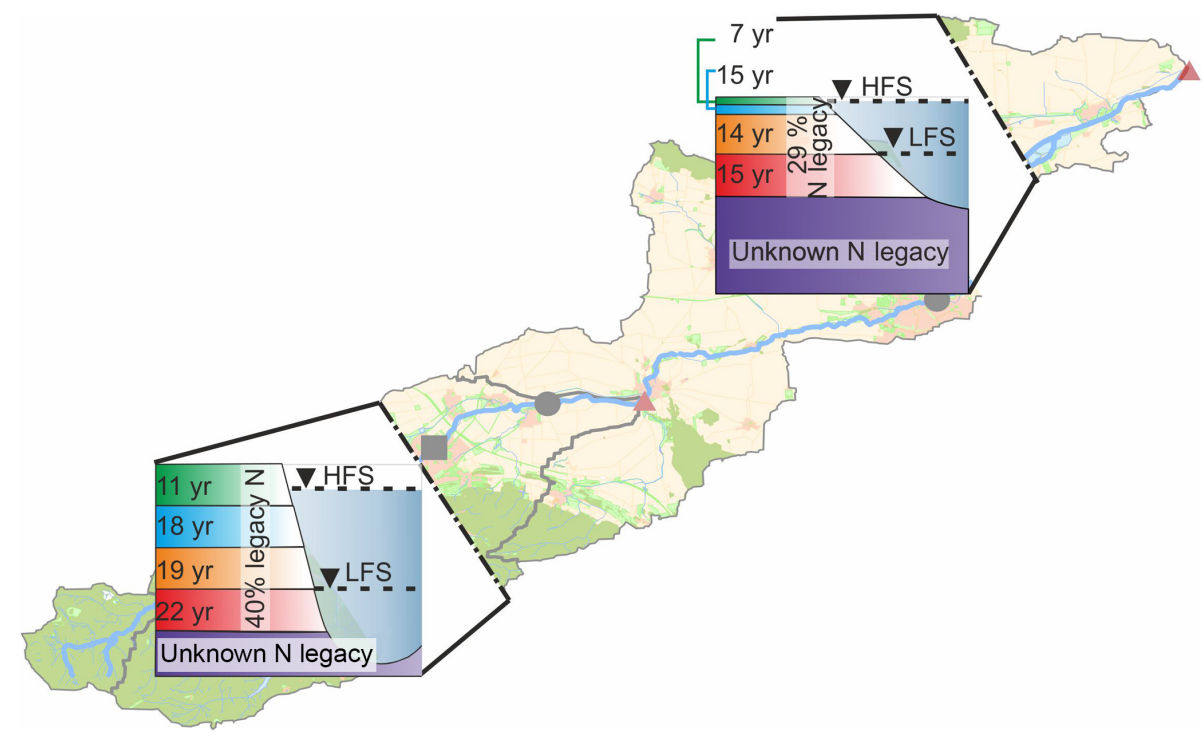

Figure 7. Conceptual model of nitrogen legacy and exports from the midstream and the downstream catchments. The four stacked boxes refer to the dominant source layer of nitrate that is activated with changing water level and catchment wetness during low-flow seasons fall (red) and autumn (orange) as well as high-flow seasons winter (blue) and spring (green). Numbers in the boxes refer to peak travel times of each season. The percentages refer to the $\mathrm{N}$ imbalance between input and output explainable by travel times (hydrological legacy). Background map created from ATKIS data.

input is one of the most likely plausible explanations for our observations with regard to $\mathrm{N}$ budgets, concentrations and $C-Q$ trajectories.

The faster TTs observed at the midstream station during HFSs are assumed to be dominated by discharge from shallow (near-surface) source zones. This zone is responsible for the fast response of instream $\mathrm{NO}_{3}-\mathrm{N}$ concentrations to the increasing $\mathrm{N}$ inputs (1970s to mid-1980s). This faster lateral transfer, especially in spring (shortest TT), may be also enhanced by the presence of artificial drainage structures such as tiles and ditches. In line with the longer TTs during the LFSs, low-flow $\mathrm{NO}_{3}-\mathrm{N}$ concentrations were less impacted in the 1970s to mid-1980s as deeper parts of the aquifer were still less affected by anthropogenic inputs. With time and a downward migration of the high $\mathrm{NO}_{3}-\mathrm{N}$ inputs before 1990, those deeper layers and thus longer flow paths also delivered increased concentrations to the stream (1990s). In parallel with the increasing low-flow concentrations (in the 1990s), the spring concentrations of $\mathrm{NO}_{3}$ decreased, caused by a depletion of the shallower $\mathrm{NO}_{3}-\mathrm{N}$ stocks (see also Dupas et al., 2016; Thomas and Abbott, 2018). This depletion of the stocks was a consequence of drastically reduced $\mathrm{N}$ input after the German reunification in 1989. This conceptual model of $\mathrm{N}$ trajectories is supported by the changing $C-Q$ relationship over time. The seasonal cycle started with increasing $\mathrm{NO}_{3}-\mathrm{N}$ maxima during high flows and minima during low flows, since shallow source zones were getting loaded with $\mathrm{NO}_{3}$ first. Consequently, the accretion pattern was intensified in the first decades, accompanied by an increase in $\mathrm{CV}_{C} / \mathrm{CV}_{Q}$. The resulting positive $C-Q$ relationship on a seasonal basis was found in many agricultural catchments worldwide (e.g., Aubert et al., 2013; Martin et al., 2004; Mellander et al., 2014; Rodríguez-Blanco et al., 2015; Musolff et al., 2015). However, after several years of deeper migration of the $\mathrm{N}$ input, the catchment started to exhibit a chemostatic $\mathrm{NO}_{3}$ export regime (after the 1990s), which was manifested in the decreasing $\mathrm{CV}_{C} / \mathrm{CV}_{Q}$ ratio. This stationarity could have been caused by a vertical equilibration of $\mathrm{NO}_{3}-\mathrm{N}$ concentrations in all seasonally activated depth zones of the soils and aquifers after a more stable long-term $\mathrm{N}$ input after 1995. According to the 50th percentile of the derived TT, after 20 years only $50 \%$ of the input had been released at the midstream station. Therefore without any strong changes in input, the chemostatic conditions caused by the uniform, vertical $\mathrm{NO}_{3}-\mathrm{N}$ contamination will remain. At the same time, this chemostatic export regime supports the hypothesis of an accumulated $\mathrm{N}$ legacy rather than denitrification as the dominant reason for the imbalance between input and output.

At the downstream station, the riverine $\mathrm{NO}_{3}$ concentrations during high flows were dominated by inputs from the midstream subcatchment, which explains the similarity with the midstream bimodality in concentrations as well as the comparable TTs. The reason for these dominating midstream flows is the strong precipitation gradient resulting in a runoff gradient on the leeward side of the mountains. During low flows, the downstream subcatchment can contribute much more to discharge and therefore to the overall $\mathrm{N}$ export. During the LFSs, we observed higher $\mathrm{NO}_{3}-\mathrm{N}$ concentrations with a unimodal trajectory and shorter TTs compared to the midstream subcatchment. We argue that the lowland sub- 
catchment supports higher water levels and thus faster TTs during the low flows. Greater prevalence of young streamflow in flatter lowland terrain was also described by Jasechko et al. (2016). But besides the earlier peak time during low flows, the concentration was found to be much higher than at the midstream station. To cause such high intra-annual concentration changes, the downstream $\mathrm{NO}_{3}-\mathrm{N}$ load contribution, e.g., during the concentration peak of 1995-1996, had to be high: the summer season export was $46 \mathrm{t}$, which is more than twice the median contribution during summer $(22 t)$. A more effective export from the downstream catchment happened mainly during LFSs, which is also supported by the narrower TTD (small shape factor $\sigma$ ) in the summer and fall (Fig. 5b). The difference between the 75th and 25th percentiles (5 years) was also the smallest of all seasons in the summer at the downstream station. This could be one reason for the high concentrations in comparison to the midstream catchment and during the HFSs.

In contrast to the midstream catchment, the $C-Q$ trajectory in the downstream catchment temporarily switched from an enrichment pattern, dominated by the high concentration during high flows from the midstream catchment to a dilution pattern and a chemodynamic regime, when the high concentrations in the LFS from the downstream subcatchment dominated. Although the low-flow concentrations were slowly decreasing in the 2000s and 2010s, the downstream catchment also finally evolved to a chemostatic $\mathrm{NO}_{3}$ export regime, as was noticed at the midstream station (Fig. 6f).

Our findings support the evolution from chemodynamic to chemostatic behavior in managed catchments, but also emphasize that changing inputs of $\mathrm{N}$ into the catchment can lead to fast-changing export regimes even in relatively slowly reacting systems. Our findings expand on previous knowledge (Basu et al., 2010; Dupas et al., 2016) as we could show systematic interannual $C-Q$ changes that are in line with a changing input and a systematic seasonal differentiation of TTs. Although our study showed chemostatic behavior towards the end of the observation period (mid- and downstream; Fig. 6e-f), this export regime is not necessarily stable as it depends on a continuous replenishment of the legacy store. Changes in the $\mathrm{N}$ input translate to an increase in spatial heterogeneity in $\mathrm{NO}_{3}-\mathrm{N}$ concentrations in soil water and groundwater with contrasting water ages. The seasonally changing contribution of different water ages thus results in more chemodynamic $\mathrm{NO}_{3}$ export regimes. As described in Musolff et al. (2017), both export regimes and patterns are therefore controlled by the interrelation of TT and source concentrations. We argue that a hydrological legacy of $\mathrm{NO}_{3}$ in the catchment has been established that resulted in the pseudo-chemostatic export behavior we observe nowadays. This supports the notion that a biogeochemical legacy corresponding to the buildup of organic $\mathrm{N}$ in the root zones of the soil (van Meter et al., 2016) is less probable. If we assume that all of the $88 \%$ of the $\mathrm{N}$ input is accumulating in the soils, we cannot explain the observed shorter-term in- terannual concentration changes and trajectory in the $C-Q$ relationships. We would rather expect a stronger and even growing dampening of the $\mathrm{N}$ input to the subsurface with the buildup of a biogeochemical legacy in the form of organic $\mathrm{N}$. However, we cannot fully exclude the accumulation of a protected pool of soil organic matter with very slow mineralization rates as described in van Meter et al. (2017). Our conceptual model assigns the missing $\mathrm{N}$ to the long TTs of $\mathrm{NO}_{3}-$ $\mathrm{N}$ in soil water and groundwater and in turn to a pronounced hydrological legacy. In the midstream subcatchment, the estimated TTD explains $40 \%$ of the retained $\mathrm{NO}_{3}-\mathrm{N}$, comparing the convolution of TTD with the $\mathrm{N}$ input time series to the actual riverine export. The remaining $60 \%$ cannot be fully explained at the moment and may be assigned to a permanent removal by denitrification (see discussion above), to a fixation due to the biogeochemical legacy or to more complex (e.g., longer tailed) TTDs, which are not well represented by our assumed log-normal distribution. In the downstream subcatchment, our approach explains $29 \%$ of the observed export. This could in principle be caused by the same processes as described for the midstream subcatchment. A hydrological legacy store in deeper zones without significant discharge contribution is also possible (Fig. 7). That mass of $\mathrm{N}$ is either bypassing the downstream monitoring station (note that the downstream station is still $3 \mathrm{~km}$ upstream of the Holtemme catchment outlet) or is affected by a strong time delay and dampening not captured by our approach. Consequently, future changes in $\mathrm{N}$ inputs will also change the future export patterns and regimes, since this would shift the homogeneous $\mathrm{NO}_{3}-\mathrm{N}$ distributions in vertical soil and groundwater profiles back to more heterogeneous ones.

\section{Conclusion}

In the present study we used a unique time series of riverine $\mathrm{N}$ concentrations over the last four decades from a mesoscale German catchment as well as estimated $\mathrm{N}$ input to discuss the linkage between the two on annual and intra-annual timescales. From the input-output assessment, the buildup of a potential $\mathrm{N}$ legacy was quantified, effective TTs of nitrate were estimated and the temporal evolution to chemostatic $\mathrm{NO}_{3}-\mathrm{N}$ export was investigated. This study provides four major findings that can be generalized and transferred to other catchments of similar hydroclimatic and landscape settings as well.

First, the retention capacity of the catchment for $\mathrm{N}$ is $88 \%$ of the N input (input and output referring to 1976 to 2015), which either can be stored as a legacy or denitrified in the terrestrial or aquatic system. Although we could not fully quantify denitrification, we argue that this process is not the dominant one in the catchment to explain input-output differences. The observed $\mathrm{N}$ retention can be more plausibly explained by legacy than by denitrification. As a consequence, the hydrological $\mathrm{N}$ legacy, i.e., the load of nitrate 
still on the way to the stream, may have strong effects on future water quality and long-term implications for river water quality management. With a median export rate of $162 \mathrm{t}$ $\mathrm{Na}^{-1}$ (1976-2016, downstream station, $6 \mathrm{~kg} \mathrm{~N} \mathrm{ha}^{-1} \mathrm{a}^{-1}$ ), a depletion of this legacy $(<46000 \mathrm{tN})$ via baseflow would maintain elevated riverine concentrations for the next few decades. Although $\mathrm{N}$ surplus strongly decreased after the 1980s, during the past 10 years there was still an imbalance between agricultural input and riverine export by a mean factor of 5 (assuming the temporal offset of peak TTs between input and output of 12 years). This is a nonsustainable condition, regardless of whether the retained nitrate is stored or denitrified. Export rates as well as retention capacity derived for this catchment were found to be comparable to findings of other studies in Europe (Worrall et al., 2015; Dupas et al., 2015) and North America (van Meter et al., 2016).

Second, we derived peak time lags between $\mathrm{N}$ input and riverine export between 7 and 22 years with systematic differences among the different seasons. Catchment managers should be aware of these long time frames when implementing measures and when evaluating them. This study explains the seasonally differing lag times and temporal concentration evolutions with the vertical migration of the nitrate and their changing contribution to discharge by seasonally changing aquifer connection. Hence, interannual concentration changes are not dominantly controlled by interannually changing discharge conditions, but rather by the seasonally changing activation of subsurface flows with differing ages and thus differing $\mathrm{N}$ loads. As a consequence of this activation-dependent load contribution, an effective, adapted monitoring needs to cover, different discharge conditions when measures shall be assessed for their effectiveness. In the light of comparable findings of long time lags (van Meter and Basu, 2017; Howden, 2011), there is a general need for sufficient monitoring length and appropriate methods for data evaluation like the seasonal statistics of time series.

Third, in contrast to a more monotonic change from a chemodynamic to a chemostatic nitrate export regime that was observed previously (Dupas et al., 2016; Basu et al., 2010), this study found a systematic change in the nitrate export regime from accretion over dilution to chemostatic behavior. Here, we can make use of the unique situation in East German catchments where the collapse of agriculture in the early 1990s provided a large-scale "experiment" with abruptly reduced $\mathrm{N}$ inputs. While previous studies could not distinguish between biogeochemical and hydrological legacy to cause chemostatic export behavior, our findings provide support for a hydrological legacy in the study catchment. The systematic interannual changes in $C-Q$ relationships of $\mathrm{NO}_{3}-\mathrm{N}$ were explained by the changes in the $\mathrm{N}$ input in combination with the seasonally changing effective TTs of N. The observed export regime and pattern of $\mathrm{NO}_{3}-\mathrm{N}$ suggest a dominance of a hydrological $\mathrm{N}$ legacy over the biogeochemical $\mathrm{N}$ legacy in the upper soils. In turn, observed trajectories in export regimes of other catchments may be an indicator of their state of homogenization and can be helpful to classify results and predict future concentrations.

Fourth, although we observed long TTs, significant input changes also created strong interannual changes in the export regime. The chemostatic behavior is therefore not necessarily a persistent endpoint of intense agricultural land use, but depends on steady replenishment of the $\mathrm{N}$ store. Therefore, the export behavior can also be termed pseudo-chemostatic and may further evolve in the future (Musolff et al., 2015) under the assumptions of a changing $\mathrm{N}$ input. Depending on the legacy size, a significant reduction or increase in $\mathrm{N}$ input can cause an evolution back to more chemodynamic regimes with dilution or enrichment patterns. Simultaneously, input changes affect the homogenized vertical nitrate profile, resulting in larger intra-annual concentration differences and consequently chemodynamic behavior. Hence, chemostatic behavior and homogenization may be characteristics of managed catchments, but only under constant $\mathrm{N}$ input.

Recommendations for a sustainable management of $\mathrm{N}$ pollution in the studied Holtemme catchment, also transferable to comparable catchments, focus on the two aspects: depleting past inputs and reducing future ones.

Our findings could not prove a significant loss of $\mathrm{NO}_{3}-\mathrm{N}$ by denitrification. To deal with the past inputs and to focus on the depletion of the $\mathrm{N}$ legacy, end-of-pipe measures such as hedgerows around agricultural fields (Thomas and Abbott, 2018), riparian buffers or constructed wetlands may initiate $\mathrm{N}$ removal by denitrification (Messer et al., 2012).

We could show that there is still an imbalance of agricultural $\mathrm{N}$ input and riverine export by a mean factor of 5 . A reduced $\mathrm{N}$ input due to better management of fertilizer and the prevention of $\mathrm{N}$ losses from the root zone at the present time is indispensable to enable depletion instead of a further buildup or stabilization of the legacy.

The combination of $\mathrm{N}$ budgeting, effective TTs with longterm changes in $C-Q$ characteristics proved to be a helpful tool to discuss the buildup and type of $\mathrm{N}$ legacy at catchment scale. This study strongly benefits from the availability of long time series in nested catchments with a hydroclimatic and land-use gradient. This wealth of data may not be available everywhere. However, we see the potential to transfer this approach to a much wider range of catchments with longterm observations for understanding the spatial and temporal variation and type of legacy buildup, denitrification and TTs as well as their controlling factors. Data-driven analyses of differing catchments covering a higher variety of characteristics may provide a more comprehensive picture of $\mathrm{N}$ trajectories and their controlling parameters. In addition to data-driven approaches emphasis should also be put on robust estimations of water TT in catchments to constrain reaction rates. Recent studies present promising approaches to derive TTs in groundwater (Marcais et al., 2018; Kolbe et al., 2019) and at catchment scale (Jasechko et al., 2016; Yang et al., 2018a) 
Data availability. Discharge data (for all dates) and water quality data (from 1993) can be accessed on the websites of the State Office of Flood Protection and Water Management (LHW) of Saxony-Anhalt (http://gldweb.dhi-wasy.com/gld-portal/, LHW, 2017). Water quality data for nitrate (including those prior to 1993) are available at https://doi.org/10.4211/hs.9c57af9b5c1343bb840ba198a49ace1c (Ehrhardt, 2019). Atmospheric deposition data between 1995 and 2015 can be accessed on the website of the Meteorological Synthesizing Centre - West (MSC-W) of the European Monitoring and Evaluation Programme (EMEP) (http://www.emep.int/mscw/index_mscw.html, Norwegian Meteorological Institute, 2017), which is assigned to the Meteorological institute of Norway (MET Norway).

Supplement. The supplement related to this article is available online at: https://doi.org/10.5194/hess-23-3503-2019-supplement.

Author contributions. SE carried out the analysis, interpreted the data and wrote the paper. AM designed the study and co-wrote the paper. RK contributed discharge modeling results and atmospheric deposition and co-wrote the paper. All authors contributed to the study design and helped finalize the paper.

Competing interests. The authors declare that they have no conflict of interest.

Acknowledgements. We would like to thank the State Office of Flood Protection and Water Management (LHW) of Saxony-Anhalt for supplying data for discharge and water quality. Additionally, we thank the MET Norway, as a source of data to model the atmospheric deposition. We gratefully acknowledge the provision of $\mathrm{N}$ input from agriculture by Martin Bach, University of Gießen, Germany. Christin Müller kindly provided wastewater data from the catchment. Thanks to Dietrich Borchardt, Suresh Rao, Kim van Meter, Frank Blumensaat and James Jawitz for helpful discussions. We acknowledge the valuable comments and inputs from two anonymous reviewers.

Financial support. The article processing charges for this openaccess publication were covered by a Research Centre of the Helmholtz Association.

Review statement. This paper was edited by Nandita Basu and reviewed by two anonymous referees.

\section{References}

Abbott, B. W., Moatar, F., Gauthier, O., Fovet, O., Antoine, V., and Ragueneau, O.: Trends and seasonality of river nutrients in agricultural catchments: 18 years of weekly cit- izen science in France, Sci. Total Environ., 624, 845-858, https://doi.org/10.1016/j.scitotenv.2017.12.176, 2018.

Altman, S. J. and Parizek, R. R.: Dilution of non-point source nitrate in ground water, J. Environ. Qual., 24, 11, 707-718, 1995.

Aubert, A. H., Gascuel-Odoux, C., Gruau, G., Akkal, N., Faucheux, M., Fauvel, Y., Grimaldi, C., Hamon, Y., Jaffrézic, A., LecozBoutnik, M., Molénat, J., Petitjean, P., Ruiz, L., and Merot, P.: Solute transport dynamics in small, shallow groundwaterdominated agricultural catchments: insights from a highfrequency, multisolute $10 \mathrm{yr}$-long monitoring study, Hydrol. Earth Syst. Sci., 17, 1379-1391, https://doi.org/10.5194/hess-171379-2013, 2013.

Bach, M. and Frede, H. G.: Agricultural nitrogen, phosphorus and potassium balances in Germany-Methodology and trends 1979 to 1995, Z. Pflanzenernähr. Bodenk., 161, 385-393, 1998.

Bach, M., Godlinski, F., and Greef, J.-M.: Handbuch Berechnung der Stickstoff-Bilanz für die Landwirtschaft in Deutschland Jahre 1990-2008, in: Berichte aus dem Julius Kühn-Institut 159, edited by: Julius Kühn-Institut, Federal Research Centre for Cultivated Plants, 36, Braunschweig, Germany, 2011.

Bartnicky, J. and Benedictow, A.: Atmospheric Deposition of Nitrogen to OSPAR Convention waters in the period 1995-2014, in: EMEP MSC-W Report for OSPAR EMEP/MSC-W TECHNICAL REPORT 1/2017, edited by: Meteorological Synthesizing Centre-West (MSC-W) Norwegian Meteorological Institute, 112, Oslo, Norway, 2017.

Bartnicky, J. and Fagerli, H.: Atmospheric Nitrogen in the OSPAR Convention Area in the period 1990-2004, in: Summary Report for the OSPAR Convention, edited by: Meteorological Synthesizing Centre-West (MSC-W) of EMEP, Oslo, 66, Oslo, Norway, 2006.

Basu, N. B., Destouni, G., Jawitz, J. W., Thompson, S. E., Loukinova, N. V., Darracq, A., Zanardo, S., Yaeger, M., Sivapalan, M., Rinaldo, A., and Rao, P. S. C.: Nutrient loads exported from managed catchments reveal emergent biogeochemical stationarity, Geophys. Res. Lett., 37, 1-5, https://doi.org/10.1029/2010g1045168, 2010.

Benettin, P., Kirchner, J. W., Rinaldo, A., and Botter, G.: Modeling chloride transport using travel time distributions at Plynlimon, Wales, Water Resour. Res., 51, 3259-3276, https://doi.org/10.1002/2014wr016600, 2015.

Bouraoui, F. and Grizzetti, B.: Long term change of nutrient concentrations of rivers discharging in $\mathrm{Eu}-$ ropean seas, Sci. Total Environ., 409, 4899-4916, https://doi.org/10.1016/j.scitotenv.2011.08.015, 2011.

CEC (Council of the European Communities): Council Directive 91/676/EEC of 12 December 1991 concerning the protection of waters against pollution caused by nitrates from agricultural sources (91/676/EEC), Official Journal of the European Communities, 34, 33, 1991.

CEC (Council of the European Communities): Directive 2000/60/EC of the European Parliament and of the Council of 23 October 2000 establishing a framework for Community action in the field of water policy, Official Journal of the European Communities, 43, 84, 2000.

Cleveland, C. C., Townsend, A. R., Schimel, D. S., Fisher, H., Howarth, R. W., Hedin, L. O., Perakis, S. S., Latty, E. F., Von Fischer, J. C., Elseroad, A., and Wasson, M. F.: Global patterns of terrestrial biological nitrogen $\left(\mathrm{N}_{2}\right)$ fixation 
in natural ecosystems, Global Biogeochem. Cy., 13, 623-645, https://doi.org/10.1029/1999gb900014, 1999.

Decrem, M., Spiess, E., Richner, W., and Herzog, F.: Impact of Swiss agricultural policies on nitrate leaching from arable land, Agron. Sustain. Dev., 27, 243-253, https://doi.org/10.1051/agro:2007012, 2007.

Dentener, F. J.: Global Maps of Atmospheric Nitrogen Deposition, 1860, 1993, and 2050, Oak Ridge National Laboratory Distributed Active Archive Center, Oak Ridge, Tennessee, USA, 2006.

Dupas, R., Curie, F., Gascuel-Odoux, C., Moatar, F., Delmas, M., Parnaudeau, V., and Durand, P.: Assessing $\mathrm{N}$ emissions in surface water at the national level: comparison of country-wide vs. regionalized models, Sci. Total Environ., 443, 152-162, https://doi.org/10.1016/j.scitotenv.2012.10.011, 2013.

Dupas, R., Delmas, M., Dorioz, J.-M., Garnier, J., Moatar, F., and Gascuel-Odoux, C.: Assessing the impact of agricultural pressures on $\mathrm{N}$ and $\mathrm{P}$ loads and eutrophication risk, Ecol. Indic., 48, 396-407, https://doi.org/10.1016/j.ecolind.2014.08.007, 2015.

Dupas, R., Jomaa, S., Musolff, A., Borchardt, D., and Rode, M.: Disentangling the influence of hydroclimatic patterns and agricultural management on river nitrate dynamics from subhourly to decadal time scales, Sci. Total Environ., 571, 791-800, https://doi.org/10.1016/j.scitotenv.2016.07.053, 2016.

Dupas, R., Minaudo, C., Gruau, G., Ruiz, L., and Gascuel-Odoux, C.: Multidecadal Trajectory of Riverine Nitrogen and Phosphorus Dynamics in Rural Catchments, Water Resour. Res., 54, 5327-5340, https://doi.org/10.1029/2018wr022905, 2018.

EEA (European Environment Agency): Corine Land Cover, European Environment Agency, Copenhagen, available at: https:// land.copernicus.eu/pan-european/corine-land-cover (last access: 19 October 2017), 2012.

EEA (European Environment Agency): Effects of Air Pollution on European Ecosystems, in: Past and future exposure of European freshwater and terrestrial habitats to acidifying and eutrophying air pollutants, EEA Technical report No. 11, 42, Copenhagen, Danmark, 2014.

Ehrhardt, S.: Nitrate Data for the Holtemme, https://doi.org/10.4211/hs.9c57af9b5c1343bb840ba198a49ace1c, 2019.

Elser, J. J.: A World Awash with Nitrogen, Science, 334, 15031504, https://doi.org/10.1126/science.1216124, 2011.

Elser, J. J., Bracken, M. E., Cleland, E. E., Gruner, D. S., Harpole, W. S., Hillebrand, H., Ngai, J. T., Seabloom, E. W., Shurin, J. B., and Smith, J. E.: Global analysis of nitrogen and phosphorus limitation of primary producers in freshwater, marine and terrestrial ecosystems, Ecol. Lett., 10, 1135-1142, https://doi.org/10.1111/j.1461-0248.2007.01113.x, 2007.

Federal Ministry for the Environment: Nature Conservation and $\mathrm{Nu}-$ clear Safety and Federal Ministry of Food, Agriculture and Consumer Protection: Nitrates Report 2012, edited by: Keppner, L., Rohmoser, W., Wendang, J., and Fischer, D., 90, Bonn, Germany, 2012

Frick, C., Steiner, H., Mazurkiewicz, A., Riediger, U., Rauthe, M., Reich, T., and Gratzki, A.: Central European high-resolution gridded daily data sets (HYRAS): Mean temperature and relative humidity, Meteorol. Z., 23, 15-32, https://doi.org/10.1127/09412948/2014/0560, 2014.
Frühauf, M. and Schwab, M.: Landschaftscharakter und Oberflaechengestalt, in: Geologie von Sachsen-Anhalt, Sect. 5.6.2, edited by: Bachmann, G. H., Ehling, B.-C., Eichner, R., and Schwab, M., 689, Schweizerbart'sche Verlagsbuchhandlung, Stuttgart, 2008.

Galloway, J. N., Dentener, F. J., Capone, D. G., Boyer, E. W., Howarth, R. W., Seitzinger, S. P., Asner, G. P., Cleveland, C. C., Green, P. A., Holland, E. A., Karl, D. M., Michaels, A. F., Porter, J. H., Townsend, A. R., and Vöosmarty, C. J.: Nitrogen Cycles: Past, Present, and Future, Biogeochemistry, 70, 153-226, https://doi.org/10.1007/s10533-004-0370-0, 2004.

Godsey, S. E., Kirchner, J. W., and Clow, D. W.: Concentrationdischarge relationships reflect chemostatic characteristics of US catchments, Hydrol. Process., 23, 1844-1864, https://doi.org/10.1002/hyp.7315, 2009.

Green, C. T., Jurgens, B. C., Zhang, Y., Starn, J. J., Singleton, M. J., and Esser, B. K.: Regional oxygen reduction and denitrification rates in groundwater from multi-model residence time distributions, San Joaquin Valley, USA, J. Hydrol., 543, 155-166, https://doi.org/10.1016/j.jhydrol.2016.05.018, 2016.

Gross, N.: Farming in former East Germany: Past policies and future prospects, Landscape Urban Plan., 35, 25-40, https://doi.org/10.1016/0169-2046(95)00215-4, 1996.

Hannappel, S., Köpp, C., and Bach, T.: Charakterisierung des Nitratabbauvermögens der Grundwasserleiter in Sachsen-Anhalt, Grundwasser, 23, 311-321, https://doi.org/10.1007/s00767-0180402-7, 2018.

Heidbüchel, I., Troch, P. A., Lyon, S. W., and Weiler, M.: The master transit time distribution of variable flow systems, Water Resour. Res., 48, 2637, https://doi.org/10.1029/2011wr011293, 2012.

Hirsch, R. M. and DeCicco, L. A.: EGRET: Exploration and Graphics for RivEr Trends, R package version 3.0.2, 2019.

Hirsch, R. M., Moyer, D. L., and Archfield, S. A.: Weighted Regressions on Time, Discharge, and Season (WRTDS), with an Application to Chesapeake Bay River Inputs, J. Am. Water Resour. As., 46, 857-880, https://doi.org/10.1111/j.17521688.2010.00482.x, 2010.

Hirsch, R. M., Archfield, S. A. and DeCicco, L. A.: A bootstrap method for estimating uncertainty of water quality trends, Environ. Modell. Softw., 73, 148-166, 2015.

Hofstra, N. and Bouwman, A. F.: Denitrification in Agricultural Soils: Summarizing Published Data and Estimating Global Annual Rates, Nutr. Cycl. Agroecos., 72, 267-278, https://doi.org/10.1007/s10705-005-3109-y, 2005.

Howarth, R. W., Billen, G., Swaney, D., Townsend, A., Jaworski, N., Lajtha, K., Downing, J. A., Elmgren, R., Caraco, N., Jordan, T., Berendse, F., Freney, J., Kudeyarov, V., Murdoch, P., and Zhao-Liang, Z.: Regional nitrogen budgets and riverine $\mathrm{N} \& \mathrm{P}$ fluxes for the drainages to the North Atlantic Ocean: Natural and human influences, Biogeochemistry, 35, 75-139, https://doi.org/10.1007/bf02179825, 1996.

Howden, N. J. K., Burt, T. P., Worrall, F., Whelan, M. J., and Bieroza, M.: Nitrate concentrations and fluxes in the River Thames over 140 years (1868-2008): Are increases irreversible?, Hydrol. Process., 24, 2657-2662, https://doi.org/10.1002/hyp.7835, 2010.

Howden, N. J. K., Burt, T. P., Worrall, F., Mathias, S., and Whelan, M. J.: Nitrate pollution in intensively farmed regions: What are 
the prospects for sustaining high-quality groundwater?, Water Resour. Res., 47, 13 pp., https://doi.org/10.1029/2011wr010843, 2011.

Jasechko, S., Kirchner, J. W., Welker, J. M., and McDonnell, J. J.: Substantial proportion of global streamflow less than three months old, Nat. Geosci., 9, 126-129, https://doi.org/10.1038/ngeo2636, 2016.

Jawitz, J. W. and Mitchell, J.: Temporal inequality in catchment discharge and solute export, Water Resour. Res., 47, 16 pp., https://doi.org/10.1029/2010wr010197, 2011.

Kirchner, J. W., Feng, X., and Neal, C.: Fractal stream chemistry and its implications for contaminant transport in catchments, Nature, 403, 524-527, https://doi.org/10.1038/35000537, 2000.

Kolbe, T., de Dreuzy, J. R., Abbott, B. W., Aquilina, L., Babey, T., Green, C. T., Fleckenstein, J. H., Labasque, T., Laverman, A. M., Marcais, J., Peiffer, S., Thomas, Z., and Pinay, G.: Stratification of reactivity determines nitrate removal in groundwater, P. Natl. Acad. Sci. USA, 116, 2494-2499, https://doi.org/10.1073/pnas.1816892116, 2019.

Kuhr, P., Kunkel, R., Tetzlaff, B., and Wendland, F.: Räumlich differenzierte Quantifizierung der Nährstoffeinträge in Grundwasser und Oberflächengewässer in Sachsen-Anhalt unter Anwendung der Modellkombination GROWA-WEKU-MEPhos, edited by: Jülich, F., 218 pp., 2014.

Kumar, R., Samaniego, L., and Attinger, S.: Implications of distributed hydrologic model parameterization on water fluxes at multiple scales and locations, Water Resour. Res., 49, 360-379, https://doi.org/10.1029/2012wr012195, 2013.

Kunkel, R., Eisele, M., and Wendland, F.: Evaluation of strategies to reduce nitrate pollution of groundwater - assessing the needs and efficiencies of agri-environmental measures for selected groundwater bodies in Germany, IWA World Water Congress, 2008.

LHW: Karte der potenziellen Entwässerungsbedürftigkeit landwirtschaftlicher Nutzfläche Sachsen-Anhalts, Landesbetrieb für Hochwasserschutz und Wasser-wirtschaft Sachsen-Anhalt, Halle/S, 2011.

LHW, Landesbetrieb für Hochwasserschutz und Wasserwirtschaft Sachsen-Anhalt: Datenportal Gewässerkundlicher Landesdienst, Fließgewässer und Seen, available at: http://gldweb.dhi-wasy. com/gld-portal/ (last access: 17 January 2018), 2017.

Marcais, J., Gauvain, A., Labasque, T., Abbott, B. W., Pinay, G., Aquilina, L., Chabaux, F., Viville, D., and De Dreuzy, J. R.: Dating groundwater with dissolved silica and CFC concentrations in crystalline aquifers, Sci. Total Environ., 636, 260-272, https://doi.org/10.1016/j.scitotenv.2018.04.196, 2018.

Martin, C., Aquilina, L., Gascuel-Odoux, C., Molénat, J., Faucheux, M., and Ruiz, L.: Seasonal and interannual variations of nitrate and chloride in stream waters related to spatial and temporal patterns of groundwater concentrations in agricultural catchments, Hydrol. Process., 18, 1237-1254, https://doi.org/10.1002/hyp.1395, 2004.

Melland, A. R., Mellander, P.-E., Murphy, P. N. C., Wall, D. P., Mechan, S., Shine, O., Shortle, G., and Jordan, P.: Stream water quality in intensive cereal cropping catchments with regulated nutrient management, Environ. Sci. Policy, 24, 58-70, https://doi.org/10.1016/j.envsci.2012.06.006, 2012.

Mellander, P. E., Melland, A. R., Murphy, P., Wall, D., Shortle, G., and Jordan, P.: Coupling of surface water and groundwater nitrate- $\mathrm{N}$ dynamics in two permeable agri- cultural catchments, J. Agr. Sci.-Cambridge, 152, 18 pp., https://doi.org/10.1017/S0021859614000021 2014.

Messer, T. L., Burchell, M. R., Grabow, G. L., and Osmond, D. L.: Groundwater nitrate reductions within upstream and downstream sections of a riparian buffer, Ecol. Eng., 47, 297-307, https://doi.org/10.1016/j.ecoleng.2012.06.017, 2012.

Minaudo, C., Meybeck, M., Moatar, F., Gassama, N., and Curie, F.: Eutrophication mitigation in rivers: 30 years of trends in spatial and seasonal patterns of biogeochemistry of the Loire River (1980-2012), Biogeosciences, 12, 2549-2563, https://doi.org/10.5194/bg-12-2549-2015, 2015.

Mulholland, P. J., Valett, H. M., Webster, J. R., Thomas, S. A., Cooper, L. W., Hamilton, D. P., and Peterson, B. J.: Stream denitrification and total nitrate uptake rates measured using a field $15 \mathrm{~N}$ tracer addition approach, Limnol. Oceanogr., 49, 809-820, 2004.

Mulholland, P. J., Helton, A. M., Poole, G. C., Hall, R. O., Hamilton, S. K., Peterson, B. J., Tank, J. L., Ashkenas, L. R., Cooper, L. W., Dahm, C. N., Dodds, W. K., Findlay, S. E. G., Gregory, S. V., Grimm, N. B., Johnson, S. L., McDowell, W. H., Meyer, J. L., Valett, H. M., Webster, J. R., Arango, C. P., Beaulieu, J. J., Bernot, M. J., Burgin, A. J., Crenshaw, C. L., Johnson, L. T., Niederlehner, B. R., O’Brien, J. M., Potter, J. D., Sheibley, R. W., Sobota, D. J., and Thomas, S. M.: Stream denitrification across biomes and its response to anthropogenic nitrate loading, Nature, 452, 202-205, https://doi.org/10.1038/nature06686, 2008.

Müller, C., Zink, M., Samaniego, L., Krieg, R., Merz, R., Rode, M., and Knoller, K.: Discharge Driven Nitrogen Dynamics in a Mesoscale River Basin As Constrained by Stable Isotope Patterns, Environ. Sci. Technol., 50, 9187-9196, https://doi.org/10.1021/acs.est.6b01057, 2016.

Müller, C., Musolff, A., Strachauer, U., Brauns, M., Tarasova, L., Merz, R., and Knöller, K.: Tomography of anthropogenic nitrate contribution along a mesoscale river, Sci. Total Environ., 615, 773-783, https://doi.org/10.1016/j.scitotenv.2017.09.297, 2018.

Musolff, A., Schmidt, C., Selle, B., and Fleckenstein, J. H.: Catchment controls on solute export, Adv. Water Resour. Res., 86, 133-146, https://doi.org/10.1016/j.advwatres.2015.09.026, 2015.

Musolff, A., Schmidt, C., Rode, M., Lischeid, G., Weise, S. M., and Fleckenstein, J. H.: Groundwater head controls nitrate export from an agricultural lowland catchment, Adv. Water Resour. Res., 96, 95-107, https://doi.org/10.1016/j.advwatres.2016.07.003, 2016.

Musolff, A., Fleckenstein, J. H., Rao, P. S. C., and Jawitz, J. W.: Emergent archetype patterns of coupled hydrologic and biogeochemical responses in catchments, Geophys. Res. Lett., 44, 4143-4151, https://doi.org/10.1002/2017g1072630, 2017.

NLfB (Niedersächsisches Landesamt für Bodenforschung): Bericht 2005 Grundwasser, Methodenbeschreibung, EG-WRRL Bericht 2005, 58, Niedersächsisches Landesamt für Bodenforschung, Niedersächsisches Landesamt für Ökologie, Bezirksregierung Hannover, Hannover, Germany, 2005.

Norwegian Meteorological Institute: Meteorological Synthesizing Centre-West of EMEP (MSC-W of EMEP), Oslo, Norway, available at: https://www.emep.int/mscw/index.html, last access: 1 November 2017.

Otero, N., Torrentó, C., Soler, A., Menció, A., and Mas-Pla, J.: Monitoring groundwater nitrate attenuation in a regional system 
coupling hydrogeology with multi-isotopic methods: The case of Plana de Vic (Osona, Spain), Agr. Ecosyst. Environ., 133, 103113, https://doi.org/10.1016/j.agee.2009.05.007, 2009.

Prasuhn, V. and Sieber, U.: Changes in diffuse phosphorus and nitrogen inputs into surface waters in the Rhine watershed in Switzerland, Aquat. Sci., 67, 363-371, https://doi.org/10.1007/s00027-005-0774-5, 2005.

Rauthe, M., Steiner, H., Riediger, U., Mazurkiewicz, A., and Gratzki, A.: A Central European precipitation climatology Part I: Generation and validation of a high-resolution gridded daily data set (HYRAS), Meteorol. Z., 22, 235-256, https://doi.org/10.1127/0941-2948/2013/0436, 2013.

Refsgaard, J. C., Auken, E., Bamberg, C. A., Christensen, B. S., Clausen, T., Dalgaard, E., Efferso, F., Ernstsen, V., Gertz, F., Hansen, A. L., He, X., Jacobsen, B. H., Jensen, K. H., Jorgensen, F., Jorgensen, L. F., Koch, J., Nilsson, B., Petersen, C., De Schepper, G., Schamper, C., Sorensen, K. I., Therrien, R., Thirup, C., and Viezzoli, A.: Nitrate reduction in geologically heterogeneous catchments - a framework for assessing the scale of predictive capability of hydrological models, Sci. Total Environ., 468-469, 1278-1288, https://doi.org/10.1016/j.scitotenv.2013.07.042, 2014.

Rivett, M. O., Buss, S. R., Morgan, P., Smith, J. W. N., and Bemment, C. D.: Nitrate attenuation in groundwater: A review of biogeochemical controlling processes, Water Res., 42, 4215-4232, https://doi.org/10.1016/j.watres.2008.07.020, 2008.

Rode, M., Thiel, E., Franko, U., Wenk, G., and Hesser, F.: Impact of selected agricultural management options on the reduction of nitrogen loads in three representative meso scale catchments in Central Germany, Sci. Total Environ., 407, 3459-3472, https://doi.org/10.1016/j.scitotenv.2009.01.053, 2009.

Rode, M., Halbedel Née Angelstein, S., Anis, M. R., Borchardt, D., and Weitere, M.: Continuous In-Stream Assimilatory Nitrate Uptake from High-Frequency Sensor Measurements, Environ. Sci. Technol., 50, 5685-5694, https://doi.org/10.1021/acs.est.6b00943, 2016.

Rodríguez-Blanco, M. L., Taboada-Castro, M. M., Taboada-Castro, M. T., and Oropeza-Mota, J. L.: Relating nitrogen export patterns from a mixed land use catchment in NW Spain with rainfall and streamflow, Hydrol. Process., 29, 2720-2730, https://doi.org/10.1002/hyp.10388, 2015.

Rozemeijer, J. C., Klein, J., Broers, H. P., van Tol-Leenders, T. P., and van der Grift, B.: Water quality status and trends in agriculture-dominated headwaters, a national monitoring network for assessing the effectiveness of national and European manure legislation in the Netherlands, Environ. Monit. Assess., 186, 8981-8995, https://doi.org/10.1007/s10661-0144059-0, 2014.

Rozemeijer, J. C. and Broers, H. P.: The groundwater contribution to surface water contamination in a region with intensive agricultural land use (NoordBrabant, the Netherlands), Environ. Pollut., 148, 695-706, https://doi.org/10.1016/j.envpol.2007.01.028, 2007.

Samaniego, L., Kumar, R., and Attinger, S.: Multiscale parameter regionalization of a grid-based hydrologic model at the mesoscale, Water Resour. Res., 46, 25 pp., https://doi.org/10.1029/2008wr007327, 2010.

Samaniego, L., Thober, S., Kumar, R., Wanders, N., Rakovec, O., Pan, M., Zink, M., Sheffield, J., Wood, E. F., and
Marx, A.: Anthropogenic warming exacerbates European soil moisture droughts, Nat. Clim. Change, 8, 421-426, https://doi.org/10.1038/s41558-018-0138-5, 2018.

Schmidt, R.: Böden, in: Physische Geographie Deutschlands, edited by: Liedke, H. and Marcinek, J., Gotha, 1995.

Schröter, D., Zebisch, M., and Grothmann, T.: Climate Change in Germany - Vulnerability and Adaptation of Climate-Sensitive Sectors, in: Research Report 20141 253, Environmental Research of the Federal Ministry of the Environment, edited by: Environmental Research of the Federal Ministry of the Environment, Nature Conservation and Nuclear Safety, UBA-FB 000844/e, Dessau, Germany, 2005.

Schuberth, K.: Geomorphologischer Ueberblick, in: Geologie von Sachsen-Anhalt, edited by: Bachmann, G. H., Ehling, B.-C., Eichner, R., and Schwab, M., Schweizerbart'sche Verlagsbuchhandlung, Stuttgart, 689, 2008.

Sebilo, M., Mayer, B., Nicolardot, B., Pinay, G., and Mariotti, A.: Long-term fate of nitrate fertilizer in agricultural soils, P. Natl. Acad. Sci. USA, 110, 18185-18189, https://doi.org/10.1073/pnas.1305372110, 2013.

Seibert, J., Grabs, T., Köhler, S., Laudon, H., Winterdahl, M., and Bishop, K.: Linking soil- and stream-water chemistry based on a Riparian Flow-Concentration Integration Model, Hydrol. Earth Syst. Sci., 13, 2287-2297, https://doi.org/10.5194/hess-13-22872009, 2009.

Seitzinger, S. P., Harrison, J. A., Böhlke, J. K., Bouwman, A. F., Lowrance, R., Peterson, B. J., Tobias, C., and van Drecht, G.: DENITRIFICATION ACROSS LANDSCAPES AND WATERSCAPES: A SYNTHESIS, Ecol. Appl., 16, 2064-2090, https://doi.org/10.1890/10510761(2006)016[2064:DALAWA]2.0.CO;2, 2006.

Smil, V.: Nitrogen in Crop Production: An Account of Global Flows, Global Biogeochem. Cy., 13, 647-662, https://doi.org/10.1029/1999GB900015, 1999.

Sprague, L. A., Hirsch, R. M., and Aulenbach, B. T.: Nitrate in the Mississippi River and its tributaries, 1980 to 2008: are we making progress?, Environ. Sci. Technol., 45, 7209-7216, https://doi.org/10.1021/es201221s, 2011.

Thomas, Z. and Abbott, B. W.: Hedgerows reduce nitrate flux at hillslope and catchment scales via root uptake and secondary effects, J. Contam. Hydrol., 215, 51-61, https://doi.org/10.1016/j.jconhyd.2018.07.002, 2018.

Thompson, S. E., Basu, N. B., Lascurain, J., Aubeneau, A., and Rao, P. S. C.: Relative dominance of hydrologic versus biogeochemical factors on solute export across impact gradients, Water Resour. Res., 47, 20 pp., https://doi.org/10.1029/2010wr009605, 2011.

Trauth, N., Musolff, A., Knöller, K., Kaden, U. S., Keller, T., Werban, U., and Fleckenstein, J. H.: River water infiltration enhances denitrification efficiency in riparian groundwater, Water Res., 130, 185-199, https://doi.org/10.1016/j.watres.2017.11.058, 2018.

Turner, R. B. and Rabalais, N. N.: Changes in Mississippi River Water Quality this Century, BioScience, 41, 8, https://doi.org/10.2307/1311453, 1991.

van der Velde, Y., Rooij, G. H. D., Rozemeijer, J. C., van Geer, F. C., and Broers, H. P.: Nitrate response of a lowland catchment: On the relation between stream concentration and 
travel time distribution dynamics, Water Resour. Res., 46, 1-17, https://doi.org/10.1029/2010wr009105, 2010.

van Meter, K. J. and Basu, N. B.: Catchment legacies and time lags: A parsimonious watershed model to predict the effects of legacy storage on nitrogen export, PloS one, 10, e0125971, https://doi.org/10.1371/journal.pone.0125971, 2015.

van Meter, K. J. and Basu, N. B.: Time lags in watershedscale nutrient transport: An exploration of dominant controls, Environ. Res. Lett., 12, 084017, https://doi.org/10.1088/17489326/aa7bf4, 2017.

van Meter, K. J., Basu, N. B., Veenstra, J. J., and Burras, C. L.: The nitrogen legacy: Emerging evidence of nitrogen accumulation in anthropogenic landscapes, Environ. Res. Lett., 11, 035014, https://doi.org/10.1088/1748-9326/11/3/035014, 2016.

van Meter, K. J., Basu, N. B., and van Cappellen, P.: Two centuries of nitrogen dynamics: Legacy sources and sinks in the Mississippi and Susquehanna River Basins, Global Biogeochem. Cy., 31, 2-23, https://doi.org/10.1002/2016gb005498, 2017a.

van Meter, K. J., Basu, N. B., and van Cappellen, P.: SupplementTwo Centuries of Nitrogen Dynamics: Legacy Sources and Sinks in the Mississippi and Susquehanna River Basins, Global Biogeochem. Cy., 31, 22, https://doi.org/10.1002/2016GB005498, 2017b.

Vidon, P. G. F. and Hill, A. R.: Landscape controls on nitrate removal in stream riparian zones, Water Resour. Res., 40, 707, https://doi.org/10.1029/2003wr002473, 2004.

Vieweg, M., Kurz, M. J., Trauth, N., Fleckenstein, J. H., Musolff, A., and Schmidt, C.: Estimating time-variable aerobic respiration in the streambed by combining electrical conductivity and dissolved oxygen time series, J. Geophys. Res.-Biogeo., 121, 21992215, https://doi.org/10.1002/2016jg003345, 2016.

Vitousek, P. M., Aber, C. A., Howarth, R. W., Likens, G. E., Matson, P. A., Schindler, D. W., Schlesinger, W. H., and Tilman, G. D.: Human Alteration of the Global Nitrogen Cycle: Sources and Consequences, Ecol. Appl., 7, 737-750, https://doi.org/10.1890/10510761(1997)007[0737:HAOTGN]2.0.CO;2, 1997.

Wassenaar, L. I.: Evaluation of the origin and fate of nitrate in the Abbotsford Aquifer using the isotopes, Appl. Geochem., 10, 391-405, https://doi.org/10.1016/0883-2927(95)00013-A, 1995.

Webster, J. R., Mulholland, P. J., Tank, J. L., Valett, H. M., Dodds, W. K., Peterson, B. J., Bowden, W. B., Dahm, C. N., Findlay, S., Gregory, S. V., Grimm, N. B., Hamilton, S. K., Johnson, S. L., Marti, E., McDowell, W. H., Meyer, J. L., Morrall, D. D., Thomas, S. A., and Wollheim, W. M.: Factors affecting ammonium uptake in streams - an inter-biome perspective, Freshwater Biol., 48, 1329-1352, https://doi.org/10.1046/j.13652427.2003.01094.x, 2003.
Wendland, F., Bogena, H., Goemann, H., Hake, J. F., Kreins, P., and Kunkel, R.: Impact of nitrogen reduction measures on the nitrogen loads of the river Ems and Rhine (Germany), Phys. Chem. Earth Pt. A/B/C, 30, 527-541, https://doi.org/10.1016/j.pce.2005.07.007, 2005.

Wollschläger, U., Attinger, S., Borchardt, D., Brauns, M., Cuntz, M., Dietrich, P., Fleckenstein, J. H., Friese, K., Friesen, J., Harpke, A., Hildebrandt, A., Jäckel, G., Kamjunke, N., Knöller, K., Kögler, S., Kolditz, O., Krieg, R., Kumar, R., Lausch, A., Liess, M., Marx, A., Merz, R., Mueller, C., Musolff, A., Norf, H., Oswald, S. E., Rebmann, C., Reinstorf, F., Rode, M., Rink, K., Rinke, K., Samaniego, L., Vieweg, M., Vogel, H.-J., Weitere, M., Werban, U., Zink, M., and Zacharias, S.: The Bode hydrological observatory: A platform for integrated, interdisciplinary hydro-ecological research within the TERENO Harz/Central German Lowland Observatory, Environ. Earth Sci., 76, 725, https://doi.org/10.1007/s12665-016-6327-5, 2017.

Worrall, F., Burt, T. P., Howden, N. J. K., and Whelan, M. J.: Fluvial flux of nitrogen from Great Britain 1974-2005 in the context of the terrestrial nitrogen budget of Great Britain, Global Biogeochem. Cy., 23, 13 pp., https://doi.org/10.1029/2008gb003351, 2009.

Worrall, F., Howden, N. J. K., and Burt, T. P.: Evidence for nitrogen accumulation: the total nitrogen budget of the terrestrial biosphere of a lowland agricultural catchment, Biogeochemistry, 123, 411-428, https://doi.org/10.1007/s10533-015-0074-7, 2015.

Yang, J., Heidbüchel, I., Musolff, A., Reinstorf, F., and Fleckenstein, J. H.: Exploring the Dynamics of Transit Times and Subsurface Mixing in a Small Agricultural Catchment, Water Resour. Res., 54, 2317-2335, https://doi.org/10.1002/2017wr021896, 2018a.

Yang, X., Jomaa, S., Zink, M., Fleckenstein, J. H., Borchardt, D., and Rode, M.: A New Fully Distributed Model of Nitrate Transport and Removal at Catchment Scale, Water Resour. Res., 54, 5856-5877, https://doi.org/10.1029/2017wr022380, 2018b.

Zacharias, S., Bogena, H., Samaniego, L., Mauder, M., Fuß, R., Pütz, T., Frenzel, M., Schwank, M., Baessler, C., ButterbachBahl, K., Bens, O., Borg, E., Brauer, A., Dietrich, P., Hajnsek, I., Helle, G., Kiese, R., Kunstmann, H., Klotz, S., Munch, J. C., Papen, H., Priesack, E., Schmid, H. P., Steinbrecher, R., Rosenbaum, U., Teutsch, G., and Vereecken, H.: A Network of Terrestrial Environmental Observatories in Germany, Vadose Zone J., 10, 955, https://doi.org/10.2136/vzj2010.0139, 2011. 